\title{
Improving understanding of near-term barrier island evolution through multi-decadal assessment of morphologic change
}

\author{
Erika E. Lentz ${ }^{\text {a,b,* }}$, Cheryl J. Hapke ${ }^{\text {c }}$, Hilary F. Stockdon ${ }^{\text {c }}$, Rachel E. Hehre ${ }^{\text {b }}$ \\ a University of Rhode Island, Department of Geosciences, 317 Woodward Hall, 9 East Alumni Avenue, Kingston RI 02881-2019, USA \\ ${ }^{\mathrm{b}}$ U.S. Geological Survey, Woods Hole Coastal and Marine Science Center, 384 Woods Hole Road, Woods Hole, MA 02543-1598, USA \\ c U.S. Geological Survey, St Petersburg Coastal and Marine Science Center, 600 Fourth St. South St Petersburg, FL 33701, USA
}

\section{A R T I C L E I N F O}

\section{Article history:}

Received 29 March 2012

Received in revised form 17 February 2013

Accepted 19 February 2013

Available online 27 February 2013

Communicated by J.T. Wells

\section{Keywords:}

morphology change

wave run up

barrier island

landward migration

geologic framework

beach replenishment

\begin{abstract}
A B S T R A C T
Observed morphodynamic changes over multiple decades were coupled with storm-driven run-up characteristics at Fire Island, New York, to explore the influence of wave processes relative to the impacts of other coastal change drivers on the near-term evolution of the barrier island. Historical topography was generated from digital stereo-photogrammetry and compared with more recent lidar surveys to quantify near-term (decadal) morphodynamic changes to the beach and primary dune system between the years 1969, 1999, and 2009. Notably increased profile volumes were observed along the entirety of the island in 1999, and likely provide the eolian source for the steady dune crest progradation observed over the relatively quiescent decade that followed. Persistent patterns of erosion and accretion over 10-, 30-, and 40-year intervals are attributable to variations in island morphology, human activity, and variations in offshore bathymetry and island orientation that influence the wave energy reaching the coast. Areas of documented long-term historical inlet formation and extensive bayside marsh development show substantial landward translation of the dune-beach profile over the near-term period of this study. Correlations among areas predicted to overwash, observed elevation changes of the dune crestline, and observed instances of overwash in undeveloped segments of the barrier island verify that overwash locations can be accurately predicted in undeveloped segments of coast. In fact, an assessment of 2012 aerial imagery collected after Hurricane Sandy confirms that overwash occurred at the majority of near-term locations persistently predicted to overwash. In addition to the storm wave climate, factors related to variations within the geologic framework which in turn influence island orientation, offshore slope, and sediment supply impact island behavior on near-term timescales.
\end{abstract}

Published by Elsevier B.V.

\section{Introduction}

Natural and anthropogenically-induced drivers of change contribute to the long-term evolution of coastal environments over a range of timescales (Harris et al., 2005). Short-term (events, seasons, years) changes are commonly studied to evaluate their immediate impacts on coastal regions, whereas near-term (decades, half centuries) assessments can provide essential information on the morphodynamics of coastal evolution (Morton and Miller, 2005; Hapke et al., 2006; Backstrom et al., 2007; Hapke et al., 2010a). Once behaviors and trends are quantified, identifying the relative importance of drivers and controls responsible for change-storm events, human influences, sediment inputs, and geologic framework expressions-aids in anticipating future vulnerable areas and guiding decision-making in coastal regions. For

\footnotetext{
* Corresponding author at: U.S. Geological Survey, Woods Hole Coastal and Marine Science Center, 384 Woods Hole Road, Woods Hole, MA 02543-1598, USA. Tel.: + 1 508457 2238; fax: + 15084572310 .

E-mail address: elentz@usgs.gov (E.E. Lentz).
}

example, the alongshore wave climate, particularly as driven by major storms, can shape the behavior and morphology of a dunes and beaches by focusing overwash through repeat events, thereby creating areas more vulnerable to dramatic change (Sallenger, 2000; Stockdon et al., 2007). Similarly, the geologic framework-the morphology, antecedent geology and underlying stratigraphy-of a coastal system has been linked to the presence of nearshore features and longer-term expressions of shoreline variations in a number of coastal regions (Schwab et al., 2000; McNinch, 2004; Harris et al., 2005; Browder and McNinch, 2006; Schupp et al., 2006; Houser et al., 2008; Hapke et al., 2010b; Houser, 2012). Anthropogenic modifications to dunes and beaches, such as beach replenishment, increase the elevation, grade, and width of a beach, though their impacts on morphologic behavior are often poorly understood (Thornton et al., 2006; Park et al., 2009). The primary objective of this paper is to explore the dominant controls of system-wide dune-beach morphologic changes on decadal timescales. To accomplish this goal, near-term morphologic changes are quantified and examined relative to several known drivers of coastal evolution and behavior, among them: the wave climate, the geologic framework, and ongoing replenishment activities. 
A paucity of detailed historical topographic datasets commonly prevents assessment of long-term morphologic change; therefore, historical coastal change is commonly assessed from shoreline datasets derived from maps, features extracted from aerial photos and widely-spaced beach profiles. However, historical surfaces can be generated with digital stereo-photogrammetry resulting in high-resolution three-dimensional (3D) datasets with continuous spatial coverage that can be directly compared with more recent (lidar) surfaces to gain a better understanding of 3D morphology change over decadal timescales (Judge and Overton, 2001; Hapke and Richmond, 2002; Hapke, 2005). The research presented here integrates photogrammetrically-derived historical topography and recent lidar datasets to examine morphologic change to the dune-beach system along the length Fire Island, New York. The topography is used to assess decadal-scale morphodynamics and changes on the barrier island from 1969 to 2009.

The 40-year span of topographic data presented in this study, which brackets a number of major storm events, has been coupled with 30 years of wave information to discern the influence of storm events, wave energy, and alongshore morphologic variation on the near-term evolution of a barrier island dune-beach system. Change is quantified specifically by: 1 ) determining subaerial volume changes through time; 2) measuring the alongshore changes, net movement, and correlations of features such as the dune crest position and elevation, shoreline position, width of the beach, and the subaerial cross-shore profile volume; and 3) evaluating these metrics in conjunction with parameterized wave run-up. The results are compared with existing theories on the influence of the geologic framework and anthropogenic modifications to gain greater insight into the near-term coastal behavior and response of barrier island systems.

\section{Regional setting}

Fire Island is centrally located in a barrier system that spans the south shore of the Long Island, New York (Fig. 1). The 50-km barrier island is oriented east-northeast, and the predominant southerly wave direction drives net longshore transport from the east to the west (Taney, 1961). Longshore transport is thought to be the dominant mechanism by which sediment moves into and through the system at Fire Island; there are no riverine sources, and limited understanding of cross shore transport volumes, timescales, and mechanisms exists (Schwab et al., 2000; Hapke et al., 2010b). Two engineered inlets bound the island and are maintained for navigation purposes: Moriches Inlet to the east, and Fire Island Inlet to the west (Fig. 1). Mean tidal range in the microtidal region is $1.3 \mathrm{~m}$ (NOAA, 2010).

The subaerial morphology of Fire Island is variable along coast. Generally, relatively narrow beaches and high dunes (some as tall as $11 \mathrm{~m}$ ) characterize the central-eastern segment of the island, whereas wider beaches and lower dunes (averaging $4.5 \mathrm{~m}$ ) are found to the west as observed in lidar from 1999 and 2009. Evidence of rapid spit growth to the west is observable in recurved dune ridges and in the historical shoreline record (Leatherman, 1985; Allen et al., 2002); from the time of construction of the Fire Island Lighthouse in 1830 to the emplacement of the inlet jetty at Democrat Point in 1942, the island grew more than $8 \mathrm{~km}$ westward (Kassner and Black, 1983; Psuty et al., 2005a) (Fig. 1). Some of the oldest and tallest dunes on the island, located between Sailor's Haven and Watch Hill, are thought to compose an ancestral barrier core (Leatherman, 1985; Leatherman and Allen, 1985; Psuty et al., 2005a, 2005b) (Fig. 1). Leatherman (1985) documented a number of historic inlets on the eastern reach of the island as evidenced by core logs, interruptions in the dune crest, and recurved dune ridges. The eastern reach of the island (roughly from Watch Hill to Moriches Inlet) exhibits more consistent landward migration patterns than the western reach with a wide flat back barrier marsh system; in fact there is no evidence of sustained breaches or inlet formation west of Watch Hill. Inlets carry sediment from the ocean to the back barrier to sustain the marsh system, and are thought to be more important than overwash in landward migration patterns at Fire Island (Leatherman, 1985, 1989).

In the late 1990s an extensive offshore mapping effort was conducted through a joint partnership between the U.S. Geological Survey and U.S. Army Corps of Engineers along the Long Island south shore innercontinental shelf (Schwab et al., 2000). The comprehensive data collection of single-channel bathymetry, sidescan sonar, and subbottom profiling shows a relatively thin veneer of modern sediment uncomformably overlying a Holocene marine transgressive (ravinement) surface along the inner shelf. In 2011, the U.S. Geological Survey conducted another geophysical survey over the inner continental shelf and lower shoreface of Fire Island, using higher resolution marine geophysical systems including interferometric swath-bathymetry and backscatter, and chirp seismic reflection profiles (Schwab et al., in press). These new bathymetry data are shown in Fig. 1. Preliminary analysis of these new data shows what was initially thought by Schwab et al. (2000) to be a submerged Cretaceous headland located offshore of Watch Hill, is in fact a lobe of Pleistocene outwash sediment (Schwab et al., in press). Erosion of this lobe of glaciofluvial sediment via oceanographic processes associated with Holocene marine transgression has supplied abundant well-sorted mediumto fine-grained sand to the inner-continental shelf downdrift to the west, which has been in turn reworked forming a series of shoreface-attached sand ridges west of Watch Hill (Schwab et al., 2000). Schwab et al. (2000) proposed that onshore flux of sediment from these ridges may be supplying the sediment volume required for maintenance of island stability west of Watch Hill and is a likely explanation for the observed historic spit growth west of Point $\mathrm{O}^{\prime}$ Woods and related modern infilling of Fire Island Inlet. East of Watch Hill, the modern reworked sediment deposit is relatively thin or absent on the inner continental shelf and lower shoreface (Fig. 1). Here, the only sediment available to supply the island is from updrift erosion and the relatively coarse-grained, less mobile Pleistocene material offshore, thus the barrier island is migrating landward at a relatively rapid rate (Schwab et al., 2000).

Nearshore (2-12 m water depth) single beam bathymetry surveys in 2007 and 2009 show that the inner shelf ridges and axial troughs are connected to the shoreface on the seaward side of the nearshore bar (Hapke et al., 2010b). The ridges are composed of well-sorted medium to fine-grained sand similar to Fire Island beach sand (Williams and Meisburger, 1987; Williams and Morgan, 1993), and could be a source of sediment to the system not currently quantified in existing sediment budget estimates at Fire Island (Williams and Meisburger, 1987; Williams and Morgan, 1993; Schwab et al., 2000). In fact, all sediment budgets conducted for the south shore of Long Island barrier system to date estimate that an average of more sediment, approximately $200,000 \mathrm{~m}^{3} / \mathrm{yr}$, is leaving the system at Fire Island Inlet than is entering the system at Moriches Inlet (Taney, 1961; Kana, 1995; Rosati et al., 1999; Hapke et al., 2010b). The lack of landward migration along the western reach of the island supports the theory that alongshore contributions from the ridges may serve as a sediment source supplying the western reach with ample material to maintain position and balance the system losses at Fire Island Inlet (Williams and Meisburger, 1987; Williams and Morgan, 1993; Schwab et al., 2000; Hapke et al., 2010b).

\subsection{Storm history}

During the time span considered in this study, a number of extratropical storms (northeasters) and hurricanes made landfall at Fire Island, resulting in elevated wave heights and periods. The extratropical storms mostly occurred in the winter and early spring, between December and early March, with winds predominantly from the east and east southeast as observed from NOAA buoy data (-buoy \#44025 shown in Fig. 1). Among these, three powerful northeasters made landfall on the south shore of Long Island between October 1991 and March 1993. The severity of the early 1990s' storms and their close temporal proximity resulted in extensive coastal flooding, overwash, and erosion along Fire 


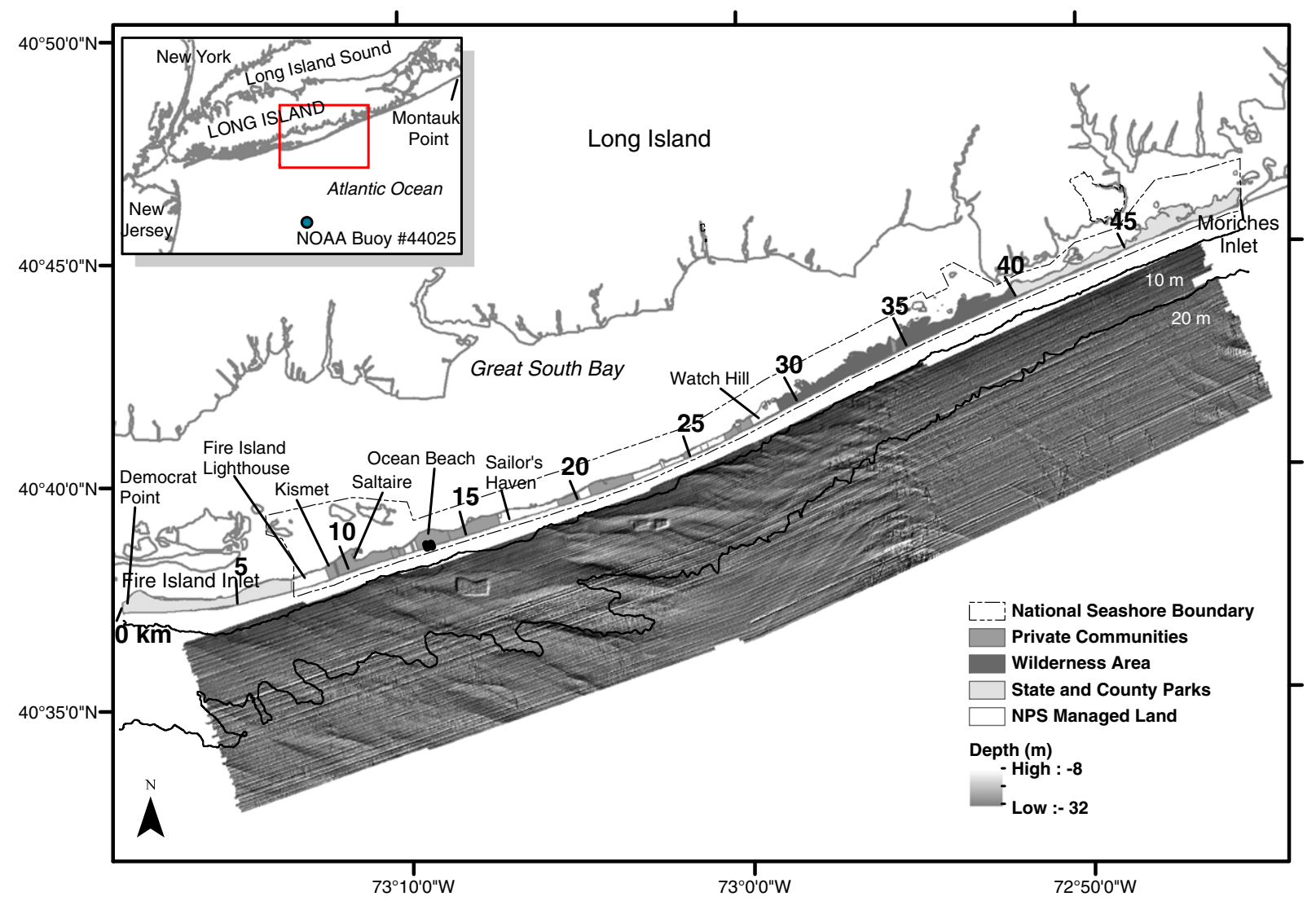

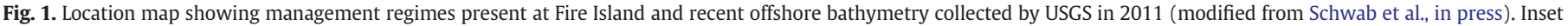
shows location of Fire Island with respect to the Long Island south shore.

Island. Significant wave heights (Hs) reached 9 m during the 1992 storm, with water levels at a nearby tidal station (Sandy Hook, New Jersey) elevated more than $2 \mathrm{~m}$.

Several strong northeasters in the last decade have caused considerable erosion on Fire Island, for example, "Nor'Ida", an extratropical storm that formed from the remnants of Hurricane Ida in 2009. The storm impacted Fire Island over a 3-day period from November 12 to 14 , and removed and mobilized substantial amounts of sediment that had been placed along the western reach of Fire Island as part of a large replenishment project that was completed in April 2009 (Fig. 2).

\subsection{Anthropogenic influences}

Fire Island contains federal, state, and county parks, a federal wilderness area, and 17 private communities (Fig. 1). With the exception of Robert Moses State Park on the western end of the island, all lie within the boundary of Fire Island National Seashore (FIIS) where the NPS manages many parcels of undeveloped land interspersed with the communities, as well as the dunes and beaches fronting both developed and undeveloped areas (Fig. 1). Although residents own their property footprints, they are required to adhere to NPS regulations for any modifications to the beaches and dunes, which prohibit the emplacement of hard engineering structures, and require permitting for soft-engineering modifications such as beach scraping and beach replenishment.

Engineered inlets on either side of Fire Island have been actively maintained for more than 50 years. Due to continued accretion of material in and around Fire Island Inlet, dredging and sediment bypassing from east to west have been active since 1971 (Psuty et al., 2005a). The stabilization of Moriches Inlet in 1952-53 resulted in increased downdrift erosion along the eastern end of the island. To mitigate these impacts, dredge material removed from the inlet for navigation purposes was deposited on updrift and downdrift beaches adjacent to the inlet. Accretion of downdrift Fire Island beaches appears to suggest that the ebb tidal delta has reached capacity and natural sediment bypassing is now taking place (Allen et al., 2002). Other than the inlet jetties, the only other hardened structures on Fire Island are two groins that were emplaced near Ocean Beach prior to the establishment of the National Seashore in 1962.

Beach replenishment projects have been conducted intermittently since the 1960s to help mitigate erosion threatening oceanfront homes and infrastructure (Valverde et al., 1999; Keehn, 2004; Psuty et al., 2005a; CP\&E, 2009). A history of beach replenishment and approximate estimates of volumes emplaced on dunes and beaches is shown in Fig. 2. Prior to the 1990s, sediment used in replenishment projects was obtained from inland sources; since 1994, sediment used for beach replenishment has been dominantly dredged from the adjacent inner continental shelf. Offshore borrow pits are centrally visible in Fig. 1. Smith Point County Park beaches on the easternmost end of the island have been regularly replenished but dates and amounts of material associated with these projects are poorly documented. The most recent large-scale replenishment project on Fire Island was completed in the spring of 2009, in which nearly 1.4 million $\mathrm{m}^{3}$ of material dredged from the offshore sand ridges was emplaced on the dunes and beaches fronting 11 communities in western and central Fire Island, as well as Fire Island Pines and Davis Park (Fig. 2).

The erosion as well as extensive damage and loss of many homes at Fire Island during the 1990s' storms prompted communities to implement beach scraping. Beach scraping is the transport of material from the dry subaerial beach to the back of the beach to reconstruct or enhance a primary dune. Kratzmann and Hapke (2012) make the case 
Fire Island Replenishment History: 1933-2012
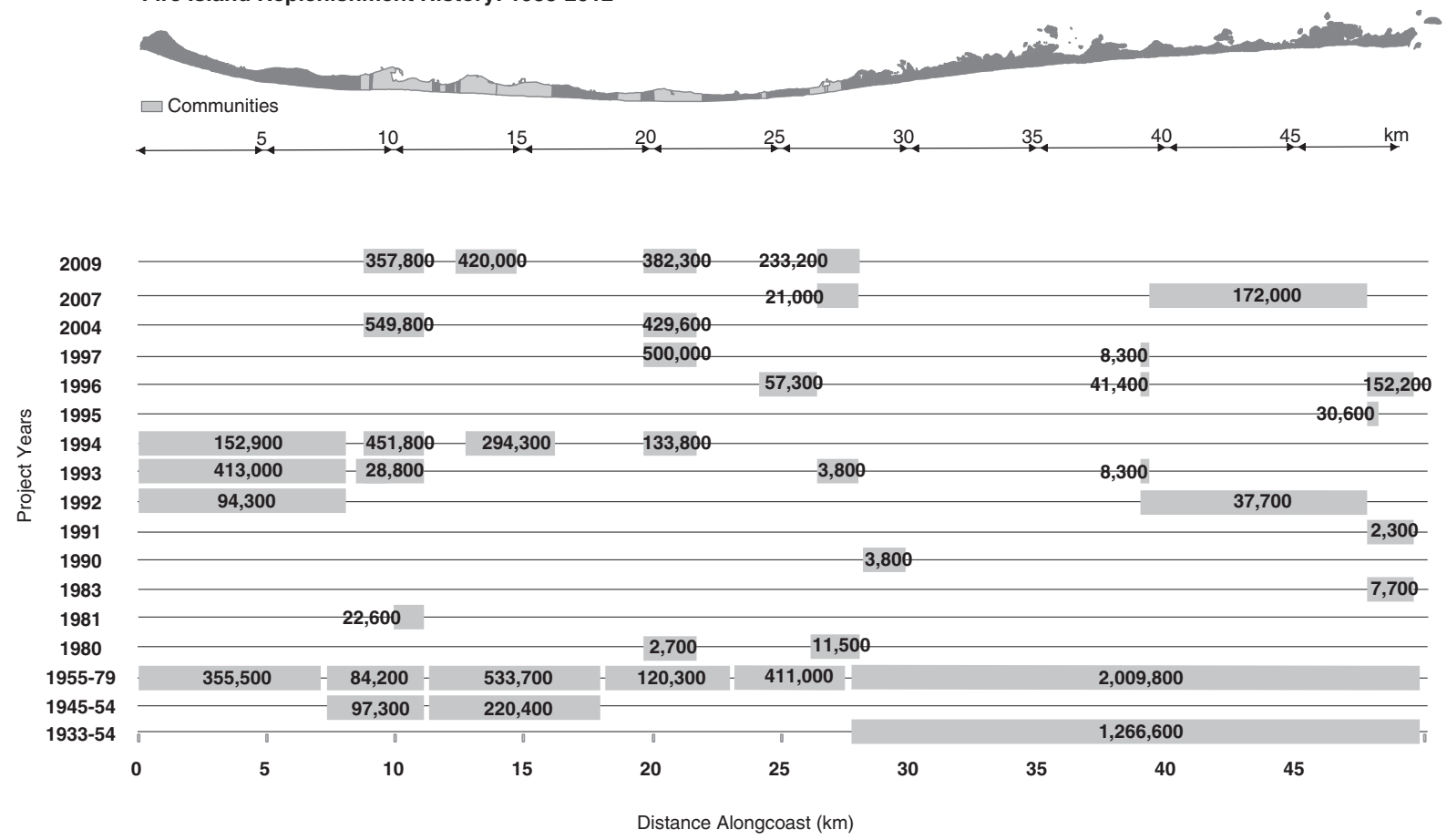

Gray boxes denote approximate locations of sand emplaced on oceanfront beaches; emplaced volumes (m3) are shown in bold. Mud emplaced in surf zone is not included. Information is based on appendix in CP\&E report which sources CENAN, Suffolk County, LUES and Duke University records, as well as the following report: Gravens, M.B., J.D. Rosati, and R.A. Wise, 1999, Fire Island Inlet to Montauk Point reformulation study (FIMP): historical and existing condition coastal processes assessment: USACE Draft Report, CHL-99-xx, $307 \mathrm{pp}$.

Fig. 2. Fire Island replenishment history showing approximate volumes and spatial locations of emplacement along shore. Data from Gravens et al., 1999.

that beach scraping has been shown to offer minimal short-term protection. However, scraping is typically conducted in some, if not many communities annually, as the visible presence of scraped dunes provides a sense of security to residents whose homes are threatened by erosion.

\section{Materials and methods}

\subsection{Topographic surfaces}

Historical topography was derived from 1969 aerial photography (B\&W, 1:12,000 scale). Using methods following Hapke and Richmond (2002) and Hapke (2005), topography was generated from the digital images (1200 dpi resolution) with stereo-photogrammetric software (SocetSet 5.0). Ground control points to which the model was referenced were extracted from a variety of stationary features identifiable in both 1969 and recent aerial imagery on the island including hard structures (i.e. sidewalks, road intersections, bulk heads) in developed areas, and distinctive features in undeveloped areas such as boulders, mosquito ditches, and surge channel locations. Control point elevations were acquired from 2002 lidar data. Once the model is spatially referenced, the software enables the user to generate a Digital Terrain Model (DTM) consisting of an extensive grid of XYZ points which can be manually edited to remove structures such as homes and trees and ensure model accuracy on the ground. Vertical root mean square errors (RMSE) from the photogrammetric processing are reported in Hehre and Hapke (2010) at $0.4 \mathrm{~m}$ (Table 1). Further detail regarding the processing and validation of stereo photogrammetric models in the coastal zone is well documented in the published literature (see Hapke, 2009; Hapke and Richmond, 2000, 2002; Hapke, 2005). Triangulated irregular network (TIN) surfaces were built from the XYZ DTM points. Onemeter resolution grids were then generated from the TIN surfaces through natural neighbors interpolation, using methods described in Lentz and Hapke (2011). Surface interpolation errors (RMSE) were determined by removing $10 \%$ of the existing points, interpolating the surface, and overlaying these points on the surface to gauge the accuracy of the interpolation (Lentz and Hapke, 2011) (Table 1).

Lidar data from October 1999 and December 2009 were used to generate more recent topographic surfaces of the dunes and beaches on the island. The 1999 dataset was collected with the NASA Airborne Topographic Mapper (ATM) sensor through a joint collaborative effort between the U.S. Geological Survey (USGS), the NASA Observational Sciences Branch, and the NOAA Coastal Services Center. The 2009 surface was collected two weeks after Nor'Ida by the USGS using the NASA Experimental Advanced Airborne Research lidar (EAARL) laser scanner. TINs and 1-m grids were generated from lidar point data for the 1999 and 2009 data. Collection error estimates are approximately $\pm 0.8 \mathrm{~m}$ for the 1999 surface and \pm 0.3 for the 2009 surface in the horizontal direction (Table 1). The vertical error for both the ATM and EAARL systems is estimated at $\pm 0.15 \mathrm{~m}$ (Sallenger et al., 2003; Nayeghandi et al., 2011). To ensure that collection error estimates fell within a submeter range, raw points from both lidar and photogrammetric surfaces were directly assessed through a comparison with Real Time Kinematic Global Positioning System (RTK GPS) point data. Grid elevations were subtracted from true elevations on a stable surface (parking lot) and averaged to determine the average per point collection error and standard deviation (Table 2). Of the points compared, the vertical error of each surface fell within the range of estimated surface error, and the variability in error among points in the same survey did not indicate systematic offsets within the datasets (Mitasova et al., 2009) (Table 2). Raw point and surface interpolation errors (RMSE) were determined using methods described above, and total root sum of the squares (RSS) was used to estimate total error (Table 1) for each surface used in the analysis. 
Table 1

Surface date, collection error, and interpolation accuracy assessments for 3D surfaces. Collection and interpolation errors are combined to determine the total error specific to each surface used in the analysis.

\begin{tabular}{|c|c|c|c|c|c|c|}
\hline \multirow[t]{2}{*}{$\begin{array}{l}\text { Surface } \\
\text { date }\end{array}$} & \multirow[t]{2}{*}{$\begin{array}{l}\text { Data } \\
\text { type }\end{array}$} & \multicolumn{2}{|c|}{$\begin{array}{l}\text { Collection/ground } \\
\text { control error }(\mathrm{m})\end{array}$} & \multirow{2}{*}{$\begin{array}{l}\text { Surface } \\
\text { accuracy } \\
\left(\text { RMSE* }^{*}(\mathrm{~m})\right.\end{array}$} & \multicolumn{2}{|l|}{$\begin{array}{l}\text { Total error } \\
\left(\mathrm{RSS}^{* *}\right)(\mathrm{m})\end{array}$} \\
\hline & & Horizontal & Vertical & & Horizontal & Vertical \\
\hline $\begin{array}{c}\text { March 28, } \\
1969\end{array}$ & $\begin{array}{l}\text { Aerial } \\
\text { imagery }\end{array}$ & \pm 0.3 & \pm 0.23 & \pm 0.2 & \pm 1.9 & \pm 0.4 \\
\hline $\begin{array}{l}\text { October } \\
21,1999\end{array}$ & Lidar & \pm 0.8 & \pm 0.15 & \pm 0.5 & \pm 0.8 & \pm 0.5 \\
\hline $\begin{array}{c}\text { December } \\
\text { 4, } 2009\end{array}$ & Lidar & \pm 0.3 & \pm 0.15 & \pm 0.2 & \pm 0.3 & \pm 0.3 \\
\hline
\end{tabular}

* Root mean square error.

** Square root of the sum of the squares.

\subsection{Feature extraction}

The crestlines and toes of the dunes were manually digitized from each surface using elevation, hillshades, and slope maps in the lidar surfaces, and by examining the 3D displays of the historical aerial photos draped over the 1969 surface. The high resolution of the datasets makes manual delineation a viable method for these extractions. Due to impacts of nourishment and beach scraping, the position of the primary dune crest and dune toe in many cases is farther seaward than the natural crestline (see Psuty and Silveira, 2009). One objective of this analysis is to quantify near-term modification impacts and to explore the degree to which they may be influenced by wave run-up as well as affect the near-term response of the system. The dune crestlines delineated in this study for all time periods therefore reflect and incorporate human alterations as well as natural variation. We have quantified the positional uncertainty of these features following Hapke et al. (2006, 2010a) using a quadrature summation of the total horizontal error of the surface (Table 1) added to an estimated user-digitizing uncertainty of $3.0 \mathrm{~m}$. Therefore approximate uncertainties of the dune crest and dune toe positions are as follows: 1969: $3.5 \mathrm{~m}$; 1999: $3.1 \mathrm{~m}$; and 2009: $3.0 \mathrm{~m}$.

Datum-based lidar shorelines were manually digitized from lidar surfaces using elevation contours following the Mean High Water (MHW) line. The elevation determined for the shoreline is the operational MHW elevation of 0.46 m NAVD 88 (Weber et al., 2005). The 1969 historical shoreline, in contrast, was derived from photogrammetric outputs. The proxy-based wet-dry or high water line (HWL) was interpreted visually from the orthophotographs during photogrammetric processing and used as an onshore breakline in the stereo-model. In order to generate accurate elevation data from stereo-models near the surf zone, a breakline was established to anchor the model where wave run up and changing conditions could otherwise inhibit 3D visualization. In order to determine an approximate elevation for the HWL breakline, tide records for the region were acquired. Historical tide records from Sandy Hook, NJ, and Montauk Point, NY indicate that for the period of aerial photo collection (3/23/1969-3/28/1969), the

Table 2

Vertical errors for each surface determined by comparing "control points" (values of eight parking lot control points from the averages of six RTK GPS surveys) against raw point values in Lidar and photogrammetry prior to interpolation. "Test" point elevations within a $4-\mathrm{m}$ radius of the control points were subtracted and averaged to determine the average per point elevation error and standard deviation.

\begin{tabular}{llll}
\hline Data source & Date & $\begin{array}{l}\text { Average per } \\
\text { point error }(\mathrm{m})\end{array}$ & $\begin{array}{l}\text { Standard } \\
\text { deviation }(\mathrm{m})\end{array}$ \\
\hline RTK GPS & $2007-2010$ & $1.39^{*}$ & 0.28 \\
Photogrammetry & April 1969 & 0.21 & 0.14 \\
Lidar & October 1999 & 0.08 & 0.02 \\
Lidar & December 2009 & 0.05 & 0.05 \\
\hline
\end{tabular}

* Average "control point" elevation using 48 parking lot measurements. elevation of the predicted higher high tide approximates the MHW elevation (Hehre and Hapke, 2010; NOAA, 2010). As a result of this finding, the HWL was used as a proxy for MHW, and an elevation of $0.46 \mathrm{~m}$ (NAVD88) was applied to this feature (Hehre and Hapke, 2010). Similar to the dune crest and dune toe, shoreline positional uncertainty was determined by a using a quadrature summation of the total horizontal error of each surface (Table 1) by an estimated user-digitizing uncertainty of 1.0 m following Hapke and Reid (2007) Hapke et al. (2010a, 2010b) and is reported as follows: 1969: $2.1 \mathrm{~m}$; 1999: $1.3 \mathrm{~m}$; and 2009: $1.0 \mathrm{~m}$.

\subsection{Change assessments}

To evaluate change of the along-shore features, the position and positional change of each feature was assessed along cross-shore profiles spaced at 50-meter intervals. Metrics were extracted from each topographic surface to evaluate: 1) net movement or translation of the cross-shore profile; 2) areas influenced by overwash; and 3) sediment gains or losses along the profile to assess decadal and multiterm change. Metrics tabulated for all years were used to determine changes between time periods: 1969-1999 (T1); 1999-2009 (T2); and 1969-2009 (T3). To assess net movement of the shoreline and dune crest, cross-shore transects were generated using the Digital Shoreline Analysis System (DSAS) (Thieler et al., 2005) and used to calculate net movement over all periods of analysis. End point uncertainty calculations in Hapke et al. (2010a) were applied to determine net dune crest and shoreline movement uncertainty over each time period using a quadrature summation of the feature uncertainty calculated for each survey year in the respective period. This resulted in a dune crest positional uncertainty range of 4.3-4.6 m, and a shoreline positional uncertainty range of 1.6-2.5 m. By extracting elevations from the position of the 1969 dune crestline we were able to determine areas that may be influenced by overwash; areas where elevations decreased may be due to breaks in the dune crestline caused by overwash, and areas where elevation remained more or less constant were not likely to have overwashed. Vertical error of the dune crest elevation was determined by a summation in quadrature of the total vertical error of each surface for the relevant period found in Table 1, resulting in an uncertainty range of $0.5-0.6 \mathrm{~m}$. Transects predicted to overwash two or more times were converted to a KML file verified by a visual assessment of overwash in eleven sets of historical aerial imagery from 1994 to 2009 available in Google Earth. Additional aerial imagery in the wake of Hurricane Sandy was also posted to Google Earth during the writing of this manuscript. As an additional point of inquiry, we compared those transects persistently predicted to overwash in our study period with observed areas of overwash after Sandy to assess whether near-term information may aide our understanding of future storm vulnerability to the system.

In addition to positional and elevation changes, beach width and profile volumes were used to evaluate how the dune-beach system changed through time. Beach width is measured from the MHW shoreline to the dune toe. Positional uncertainties of beach width were determined using similar quadrature summations of horizontal uncertainties of shorelines and dune toes of the period, with a range of 4.6-5.3 m. Profile volumes specific to each surface were estimated from the dune crestline to the MHW shoreline using methods following Kratzmann and Hapke (2012). Volume uncertainties (vertical uncertainty of the profile for survey year * profile length) were calculated from a quadrature summation of the surveys in the period, with an average range over all periods of $24.3-38.6 \mathrm{~m}^{3} / \mathrm{m}$. Statistical assessments were applied to determine if: 1) spatial changes among features are correlated over the entire span of coast (Pearson's Product-moment Correlation); and 2) significant differences exist among the features in the modified vs. unmodified portions of the island (ANOVA). To determine independence among transects, a Moran's I statistic was run. Moran's I identifies spatial autocorrelation of a feature or metric (Legendre and Fortin, 
1989), in this case along coast. A strong positive relationship was found due to a lack of independence at a distance of $250 \mathrm{~m}$ (or 5 transects at $50 \mathrm{~m}$ spacing); based on this, a reduced $\mathrm{N}$ (degrees of freedom) was determined from the total number of transects (990) to be 198 and was used in the ANOVA. Significance is determined at $\mathrm{p}<0.05$.

\subsection{Wave run-up}

The spatial variability of morphology change along the coast was explored within the context of wave forcing, or more specifically, the interaction of alongshore uniform waves with alongshore-varying beach morphology. By modeling the storm wave run up $\left(R_{2}\right)$ for each of the three datasets, we were able to identify locations along the coast where total water levels $\left(R_{\text {high }}\right)$ would exceed the height of the dunes $\left(D_{\text {high }}\right)$ during a storm event and result in overwash, following the storm impact scaling model of Sallenger (2000). Identifying locations where overwash was likely to have occurred allowed us to directly relate observations (dune crest elevation loss from the 1969 dune crest position) with the storm wave climate (predicted overwash); identifying locations of persistent predicted overwash (predicted overwash in more than one dataset) improved our understanding of the influence of the wave climate on near-term morphology of the dune/beach system. It is important to note that although the wave energy reaching the shoreline may be variable due to the differences in offshore bathymetry, we fixed wave parameters alongshore to provide a preliminary understanding of the morphologic influence of total water elevation levels on the shoreline and how they may shape the subaerial morphology response and behavior. $\mathrm{R}_{\text {high }}$ was modeled using parameterized $R_{2}$ coupled with tide and surge information as outlined in Stockdon et al. (2006, 2007).

Following Stockdon et al. (2006), the $\mathrm{R}_{2}$ parameterization model requires the input of three variables: the deep water wave height $\left(H_{0}\right)$, wave period $\left(T_{0}\right)$, and mean beach slope $\left(\beta_{\mathrm{m}}\right)$. $\beta_{\mathrm{m}}$ was averaged along individual transects from the three sets of data (MHW to dune toe) to represent typical spatial variation along coast. To identify representative storm wave conditions of $\mathrm{H}_{\text {storm }}$ and $\mathrm{T}_{\text {storm }}$ for Fire Island, we used a combination of observational and hindcast datasets to obtain information about wave conditions during storm events at Fire Island over the last 30 years. Observations of wave conditions between 1991 and 2009 were obtained from the National Data Buoy Center (NDBC) buoy station 44025 (Fig. 1). Because no observations were available prior to 1991, hindcast Hs and T from 1980 to 1999 were acquired from the U.S. Army Corps Coastal Hydraulics Laboratory Wave Information Studies (WIS) to supplement the record. Hs from extreme storm periods in 1992 and 1999 were compared between NDBC and WIS datasets to validate hindcast data (Fig. 3). The average difference between the predicted and observed results was $0.12 \mathrm{~m}$, with a correlation of 0.8 (Fig. 4). Under-predicted hindcast Hs were corrected based on the values of the regression equation $(\mathrm{y}=$ $0.73 x+0.21)$. With the correction applied, the WIS data provide hindcasts of significant storm event parameters and were used in lieu of observational data for the period 1980 to 1991. Although the wave data do not extend over the entire period of the study, the length of the record is assumed to be sufficiently long to represent average wave climate and variations representative of conditions back to 1969. To determine a representative storm condition, the $2 \%$ exceedance value for $\mathrm{Hs}\left(\mathrm{Hs}_{2} \%\right)$-the threshold of the highest $2 \%$ of the waves based on the 30-year wave record-was used to identify and select storm events $\left(\mathrm{H}_{\text {storm }}=\mathrm{H}>\mathrm{Hs}_{2 \%}\right.$ ). The $2 \%$ threshold value specific to the earlier and stormier period (T1) (Fig. 4) was compared to the later, less stormy period (T2) because in both cases these threshold values were relatively close $(4.2 \mathrm{~m}$ vs. $3.9 \mathrm{~m})$, we elected to use an average storm value to more generally explore storm activity on morphology over the entire period. A mean $\mathrm{H}_{\text {storm }}$ value of $4.1( \pm 0.8) \mathrm{m}$ was found for the $2 \%$ exceedance observations identified over the 30 -year period. The corresponding peak wave period $\left(\mathrm{T}_{\text {storm }}\right)$ for the storm events was $10( \pm 2)$ s. Along with $\beta$ m, these parameters ( $\mathrm{H}-$ storm and $\mathrm{T}_{\text {storm }}$ ) were input into the parameterization model and used to calculate $R_{2}$.

$\mathrm{R}_{\text {high }}$ was estimated by adding $\mathrm{R}_{2}$ to a representative storm-induced, high water level $(\eta(t)$, a combination of astronomical tide and surge) of $2 \mathrm{~m}$. $\eta(\mathrm{t})$ was calculated from the 10 highest events measured by the open-coast tide gauge in Sandy Hook from January 1, 1969 through December 31, 2009 relative to NAVD 88. Once determined, $R_{\text {high }}$ was compared to 1969, 1999, and 2009 dune crest and dune toe elevations to identify areas predicted to overwash following the Sallenger (2000) storm impact scaling model ( $\mathrm{R}_{\text {high }}>\mathrm{D}_{\text {high }}$ ) (Fig. 5). The persistence of predicted overwash between each of the time periods was ranked on a scale from 0 (no overwash predicted) to 3 (persistent overwash predicted in all three dates).

\section{Results}

\subsection{All-island}

Shoreline change, beach width change, and volume change results show a mean accretional trend between 1969 and 1999 (T1), while the period from 1999 to 2009 (T2) is dominated by erosion, particularly in the eastern reach of the island (Table 3; Fig. 6). Comprehensive Pearson's Product Moment (PPM) correlation results are reported in Supplemental Materials (Tables S1 and S2), and show that these three variables are strongly correlated in T2 (PPM $>0.7$ ), particularly beach width and volume (Fig. 7A). Dune crest position change is erosional on average in $\mathrm{T} 1(-3.5 \mathrm{~m})$, which is significantly different from its mean accretional trend in $\mathrm{T} 2(6.7 \mathrm{~m})$; dune crest position retreated in the first 30 years of analysis, and has prograded substantially in the most recent decade (Table 3; Fig. 6). Beach width change and dune crest position change are inversely related in T1 (PPM of -0.5), showing that where beaches accrete and widen, dunes tend to erode, whereas in areas where beaches narrow, dunes tend to prograde, although there is no relationship between these two features in T2.

Beach width and volume change are inversely correlated between T1 and T2 (Fig. 7B), showing that areas of high aggradation lost substantial amounts in the decade to follow, and vice versa. An expected correlation between beach width and volume change is shown in both T1 and T2, however, showing that wider beaches have higher volumes of sediment in the profile, whereas narrower beaches have lower volumes of sediment in the profile (Table 3; Fig. 7B).

Dune crest and shoreline movement are strongly correlated (PPM > 0.6) in T1 only (Fig. 7C), showing that over the long term, changes related to these features parallel each other; in areas of shoreline retreat, dune crestlines can be expected to retreat as well (Fig. 6). Mean dune crest elevation is erosional in both time periods, showing a steady lowering of the dune elevation through time (Table 3). Dune crest elevation change and dune crest position change vs. overwash potential are inversely related in T1 (PPM of -0.5 ; Fig. 7D), showing that areas with high overwash potential show increased dune crest elevation loss and positional retreat. Overwash potential is also strongly correlated in both T1 and T2 (PPM of 0.9) showing that an area predicted to overwash in one time period is highly likely to again.

Total change results from 1969 to 2009 (T3) (Fig. 8) trend toward results from T1. Over the 40-year period, dune crest position and shoreline change are very strongly correlated, as are beach width and volume change (Fig. 7). More moderately correlated results (PPM of 0.5 ) from this period show a relationship between: 1) dune crest elevation change and shoreline position, and 2) dune crest elevation change and dune crest position change; in areas of shoreline retreat, dune crestlines tend to lose elevation and migrate landward. An inverse relationship exists between overwash potential and dune crest position and dune crest elevation (PPM of 0.5), showing that areas with high overwash potential tend to show dune crestline retreat and dune crest elevation loss. No relationship was observed between volume change or beach 
A

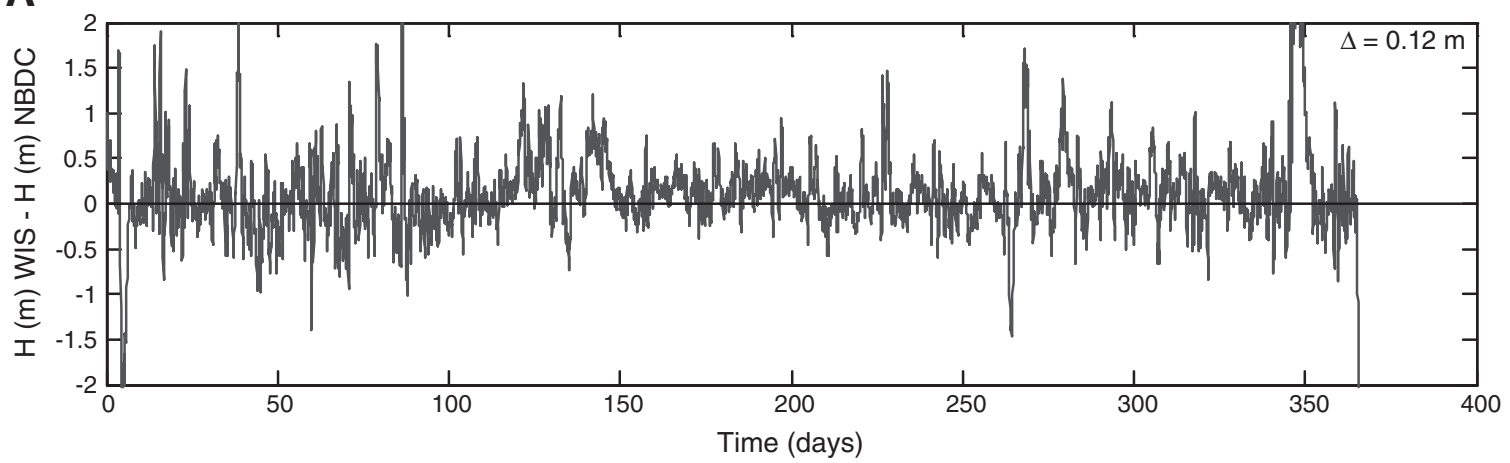

B

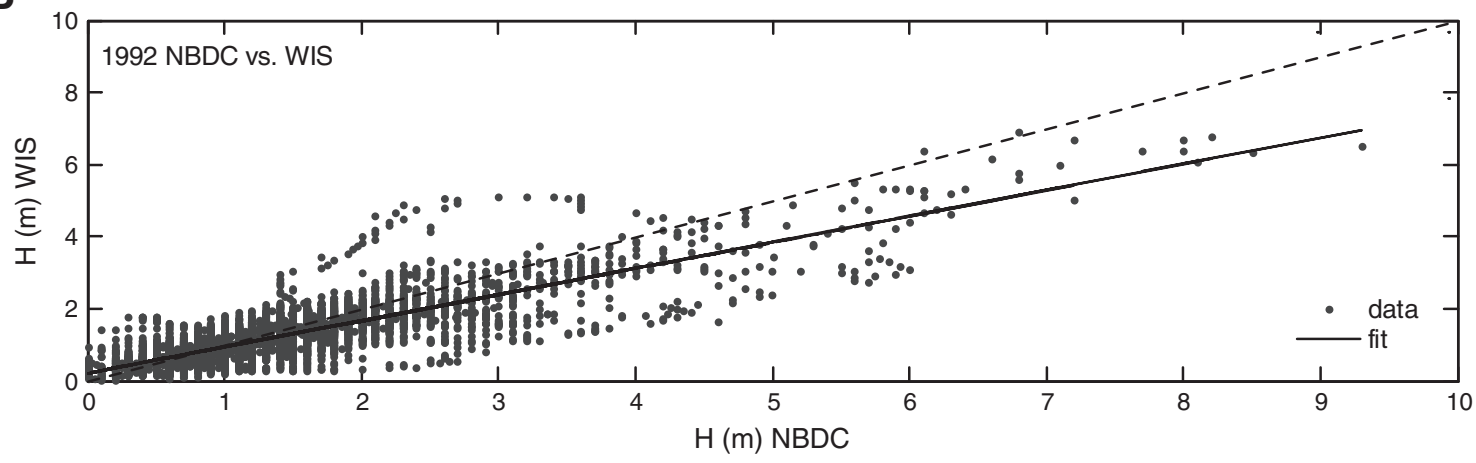

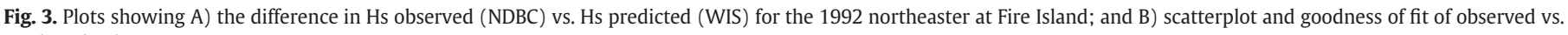
predicted values.

width and overwash potential over all time periods (PPM less than 0.3), indicating that sediment is preserved in the profile.

\subsection{Developed west vs. undeveloped areas east}

Results show substantial differences in behavior along western vs. eastern reaches of the island behavior, particularly in developed areas to the west vs. undeveloped areas to the east. Additional correlations were run on these sub-areas to determine whether trends were significant. To assess up drift and down drift development impacts, transects either directly within or within $1 \mathrm{~km}$ of the borders of developed areas were evaluated west of Watch Hill (401 transects; reduced $\mathrm{N}$ for ANOVA of 83). All transects to the east of the easternmost transect in the developed areas ( 424 transects; reduced $N$ for ANOVA of 85 ) were used to evaluate behavior of the eastern reach. Of the 990 transects assessed, persistent overwash was predicted (overwash predicted in all dataset years) at 83 transects, and overwash in two or more datasets was predicted at 421 transects.

With the exception of dune crest elevation change, ANOVA results showed average morphology changes between developed areas west (D) and undeveloped areas east (U) are significantly different between T1 vs. T2 and T2 vs. T3 (Table 3). Results also show significant differences

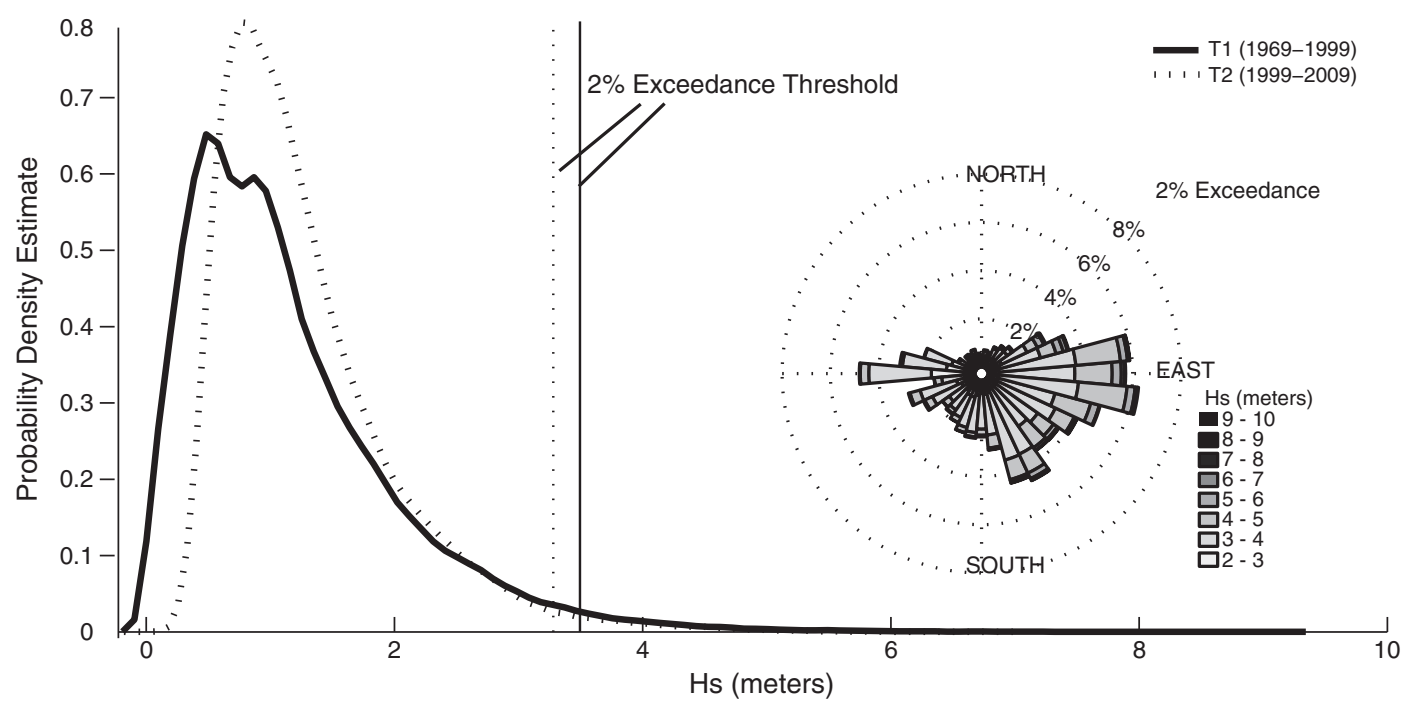

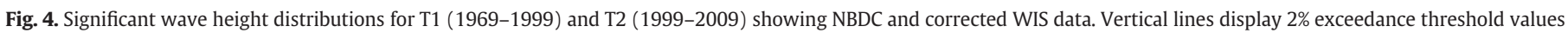
for each period. Wave rose shows dominant direction of all $2 \%$ exceedence events as based on Hs. 


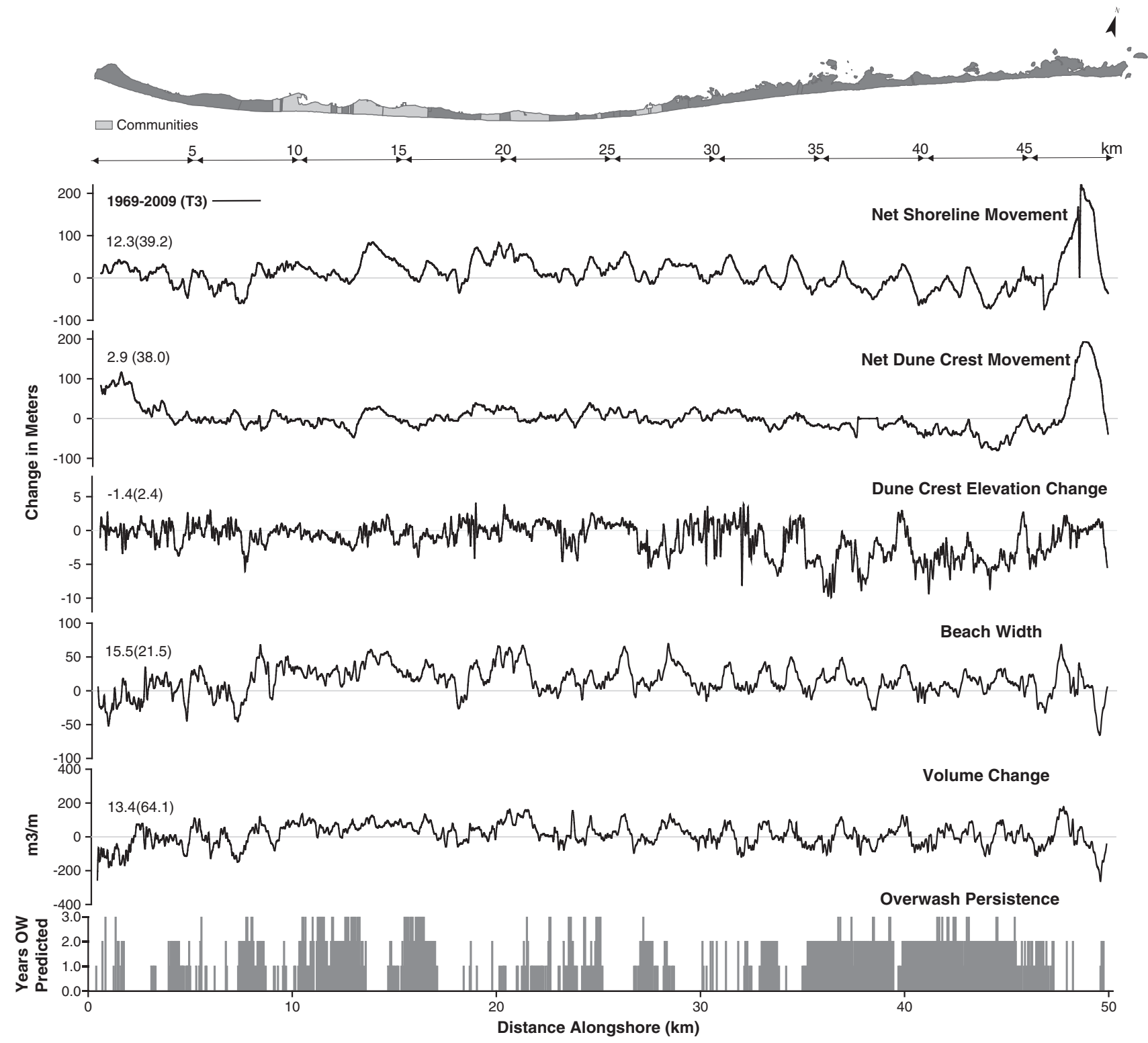

Fig. 5. Locations of predicted overwash along the coast for each dataset using the Stockdon et al. (2007) model and based on the Sallenger (2000) storm impact scale.

within time periods for shoreline movement, dune crest elevation, and beach width change. Although average changes tend to parallel each other, features that eroded in either time period eroded less in D areas than $U$ areas, and features that accreted in either time period accreted more in D areas than $U$ areas (Table 3). Total change (T3) results differed significantly in dune crest elevation change (mean of $-0.6 \mathrm{~m}$ in $\mathrm{D}$ and $-2.4 \mathrm{~m}$ in $\mathrm{U}$ ), and in volume change (mean of $44.1 \mathrm{~m}^{3} / \mathrm{m}$ in $\mathrm{D}$ and $0.2 \mathrm{~m}^{3} / \mathrm{m}$ in $\mathrm{U}$ ) showing overall gains in $\mathrm{D}$, whereas volume was largely conserved, but not gained, in U (Table 3). Average dune crest elevation showed minimal change in all three periods in $\mathrm{D}$, and a steady decline in U. Persistent overwash was equally as likely in D as in U. Out of the 83 transects predicted to persistently overwash, 43 (52\%) were in or directly adjacent to developed areas; of the 421 transects predicted to overwash in two or more periods, 254 (60\%) were in U. Assessment of Google Earth imagery in U verified that between 1994 and 2009, 83\% of those transects predicted to overwash in two or more periods displayed evidence of overwash (surge channels, overwash fans). Interestingly, in our comparison with aerial imagery taken a few days after Hurricane Sandy in 2012, we were able to verify that $69 \%$ of the transects predicted to overwash two or more times in our near-term study were spatially correlated with overwash features in the post-storm period. Similar aerial assessments were not completed in D due to the presence of human modifications in these areas; such efforts are frequently employed in a post-storm response to remove overwash material from roadways, sidewalks, and yards, and combined with development at or overlying the dune crestline, make visual observation of overwash features far less straightforward.

Moderately strong correlations (PPM $>0.5$ ) are present in $\mathrm{U}$ and not in D for shoreline movement and dune crest movement (Fig. 7), and dune crest elevation change and shoreline movement, indicating that changes in shoreline position are more directly related to changes to the dune in $\mathrm{U}$ over the long term (T1 and T3). Inverse relationships between overwash potential, shoreline change, and dune crest elevation change over all periods were stronger in $U$ than D (Tables $1 S$ and 2S), showing that areas likely to overwash in U are more likely those with eroding shorelines and that are losing dune crest elevation through time (Figs. 6 and 8).

Conversely, correlations between shoreline change and volume change and beach width change were much stronger in D (PPM > 0.6) than they were in $U$ for all periods, and a strong inverse relationship 
Table 3

Mean values and standard deviations (parens) of feature changes along the coast. First line shows change for the entire length of coast based on an independence threshold of $\sim 250 \mathrm{~m}$ (every fifth transect or a reduced $\mathrm{N}$ of 198). West encompasses those transects which directly cross or lie within $1 \mathrm{~km}$ of developed areas on the western reach $(\sim 7 \mathrm{~km})$; east encompasses those transects east of Watch Hill $(\sim 25 \mathrm{~km})$. Due to engineering influences around the inlets, these transects are not included in averages specific to eastern and western reaches.

\begin{tabular}{lllc}
\hline Parameter measured & $1969-1999$ & $1999-2009$ & $1969-2009$ \\
& $(\mathrm{~T} 1)$ & $(\mathrm{T} 2)$ & $(\mathrm{T} 3)$ \\
\hline Beach width change & $30.6(22.3)$ & $-15.2(24.7)$ & $15.5(21.5)$ \\
West (D) & $34.4(16.2)^{*+}$ & $-7.7(26.0)$ & $26.7(19.1)^{*}$ \\
East (U) & $32.0(25.0)^{+}$ & $-20.4(21.9)$ & $11.6(17.8)$ \\
Net shoreline movement & $19.7(29.7)$ & $-7.6(26.4)$ & $12.3(39.2)$ \\
West (D) & $24.3(19.4)^{*+}$ & $0.8(25.3)$ & $25.1(24.9)^{*}$ \\
East (U) & $17.1(38.6)^{*+}$ & $-12.7(23.4)$ & $4.9(49.5)^{*}$ \\
Net dune crestline movement & $-3.5(34.2)$ & $6.7(13.4)^{*}$ & $2.9(38.0)^{*}$ \\
West (D) & $-5.7(14.7)^{+}$ & $7.8(12.3)^{*+}$ & $2.1(16.6)^{*+}$ \\
East (U) & $-7.8(44.2)^{*+}$ & $5.4(14.6)^{+}$ & $-3.4(50.0)^{*+}$ \\
Volume change & $73.9(75.2)$ & $-60.5(75.4)$ & $13.4(64.1)$ \\
West (D) & $92.1(57.1)^{+}$ & $-47.9(76.4)^{+}$ & $44.1(49.7)$ \\
East (U) & $69.3(80.3)^{+}$ & $-69.1(66.3)^{+}$ & $0.2(61.0)$ \\
Dune crest elevation change & $-1.2(2.1)^{*}$ & $-0.2(1.1)$ & $-1.4(2.4)^{*}$ \\
West (D) & $-0.7(1.8)^{*}$ & $0.1(0.7)^{*+}$ & $-0.6(1.8)^{*}$ \\
East (U) & $-1.9(2.4)$ & $-0.5(1.3)^{+}$ & $-2.4(2.7)$ \\
\hline
\end{tabular}

+ Mean values between West and East in columns not significantly different.

* Mean values in rows not significantly different.

emerged between volume change and dune crest position change over the most recent decade. The strength of these relationships is important to note in areas that are known to be actively replenished.

\section{Discussion}

Although a number of studies have examined and made interpretations about the coastal evolution of barrier island systems, this study is the first to comprehensively quantify an array of near-term morphologic feature changes to the dune-beach system along the length of an island with a range of human modifications, a diversity of management practices, and well-documented variation of the inner shelf bathymetric features and antecedent geology. By correlating the near-term wave climate with observations of morphology change, we are able to examine and better isolate impacts related to other morphologic change drivers that vary spatially and are heavily timescale dependent including: 1) anthropogenic modifications (replenishment); and 2) subaerial sediment availability and the geologic framework (shoreface-attached and -detached sand ridges, glacial outwash features, and island orientation). In this discussion, we assess the likely influence of these drivers, coupled with wave processes, on near-term barrier island behavior and evolution.

\subsection{Replenishment impacts}

Similar numbers of transects in eastern and western reaches at Fire Island are predicted to overwash. However, the correlations between transects likely to overwash and observed profile morphology changes are stronger in the undeveloped eastern than the moderately developed western reach. More than $50 \%$ of the transects predicted to persistently overwash in the western reach were within or immediately adjacent to developed areas. This may be a result of inaccuracies in the predictions, but it is also likely due to ongoing anthropogenic modifications in the western areas which may prevent, rapidly erase, or minimize event-driven impacts.

The data examined in this study (Figs. 6 and 8) show that sediment volumes have increased in areas west of Watch Hill, where there has been period replenishment, during the total period with limited shoreline and dune crestline erosion (Fig. 9a-c). Temporal constraints of the datasets make several events important to consider when interpreting these results. Changes to the beach in $\mathrm{T} 2$ and $\mathrm{T} 3$ include the storm impacts from Nor'Ida; although some post-storm recovery is likely to have occurred when the lidar survey was collected, it is unlikely that the beach fully recovered in 2.5 weeks between the storm and the survey. Results also suggest that anthropogenic modifications, particularly the 2009 replenishment, are exerting some influence on the post-storm morphology of the western reach; in T2 net shoreline movement and beach width change in the western reach are significantly different from those in the eastern reach. Both the shoreline and beach width are the most likely features to be impacted by replenishment. Additionally, it is notable that, on average, dune crestlines and shorelines prograded in the western developed areas whereas they did not in undeveloped areas. Overall, volume and beach width changes experienced half the losses observed in undeveloped areas over nearly all time periods. Over the 40-year period (T3), dune crest elevation changes in the western reach are generally negligible, and dune crest positions have accreted through time; that the dune retains form despite persistent vulnerability to overwash in many locations may be due to human maintenance of the profile via replenishment and beach scraping (Figs. 9a-c).

Although coastal structures and development have been shown to contribute to vulnerability at Fire Island by restricting eolian transport, thereby restricting the growth and migration dunes which serve as natural storm buffers (Nordstrom and McCluskey, 1985), the dunes fronting many of these developed areas are actually located seaward of the natural dune feature in order to protect homes (Psuty and Silveira, 2009). Dune construction and position (lower in elevation, less compacted, and farther seaward than natural features), make them both purposefully vulnerable to storms and easily rebuilt. Because dune crestline retreat and elevation loss have been limited by human activities in the coastal communities in western Fire Island, the beach and dune system appears more morphologically stable than areas further east. However, the inverse relationship between dune crest position change (dominantly progradation) and volume change (dominantly erosion) in developed areas over the most recent decade (T2) may suggest that the profile, which has been artificially translated seaward from replenishment and scraping, is more prone to volume loss (Figs. 9a-c).

\subsection{Sediment availability and the geologic framework}

The physiography of the inner-continental shelf offshore of Fire Island is an expression of antecedent geology and oceanographic processes associated with marine transgression (Schwab et al., 2000). The inner-continental shelf can be separated into two physiographic segments. A slightly steeper gradient shelf lies to the east and a slightly gentler shelf to the west blanketed by a series of shoreface-attached sand ridges. The segments are separated by a submerged headland composed of Pleistocene glaciofluvial sediment off central Fire Island, an outwash lobe (Schwab et al., in press). A number of recent studies have observed offshore controls on shoreline behavior, dune configuration, and nearshore morphology (Riggs et al., 1995; McNinch, 2004; Harris et al., 2005; Browder and McNinch, 2006; Schupp et al., 2006; Hapke et al., 2010b; Houser, 2012). Schwab et al. (in press) make the case that long-term shoreline change rates at Fire Island are likely linked with inner shelf features and bathymetry. The array of subaerial morphology changes quantified in this study over the 30 and 40-year periods at Fire Island show different migration rates and behaviors between eastern and western reaches of the island, suggesting that the inner-shelf geologic framework is likely an important control on near-term barrier island evolution, both in terms of sediment availability along the coast and in influencing the wave climate.

The shift in island orientation from east (northeast-southwest) to west (more east-west) at approximately the location of Watch Hill (Fig. 1), coupled with the predominant easterly direction of the most intense storm waves (Fig. 4) and differences in offshore slope gradients, are important factors to consider in the measured morphologic differences between the east and west reaches of Fire Island. Although this 


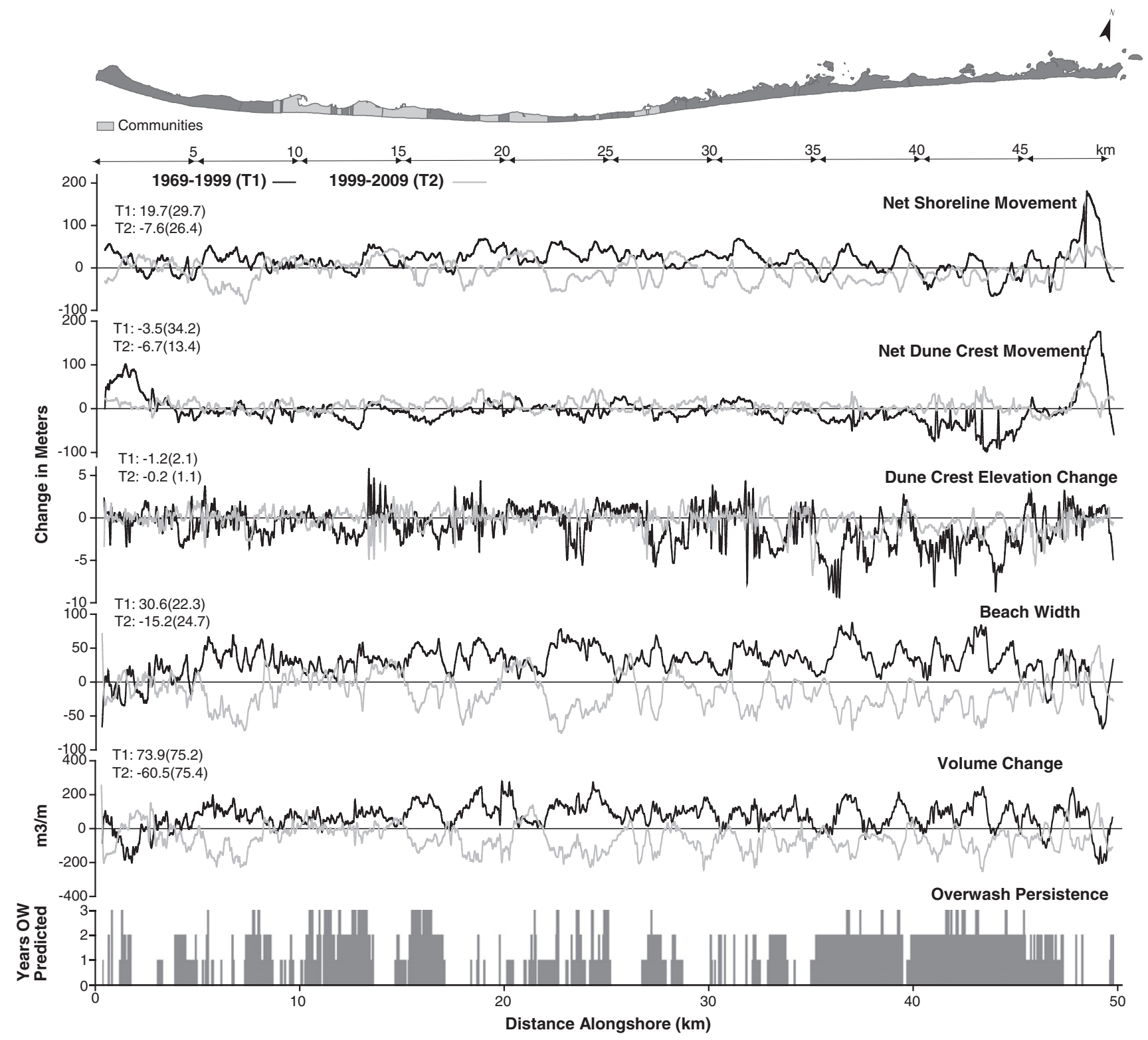

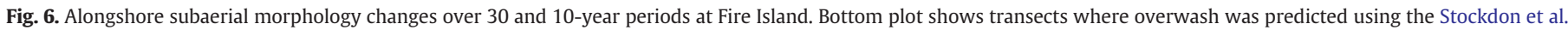
(2007) model and based on the Sallenger (2000) storm impact scale. Mean and standard deviations (parens) for each time period are reported on each plot.

study was limited in scope to focus on morphologic response to a generic storm and wave climate, it is likely that major storms, which tend to have a dominant wave propagation from the east and southeast (Fig. 4), coupled with the more southeast facing eastern reach of the island and steeper shelf result in stronger and higher waves impacting onshore areas east of Watch Hill. In addition, many have suggested that the ridge and trough system found as part of the inner continental shelf framework off western Fire Island (Fig. 1) may be serving as a source of sediment to the system west of Watch Hill, as well as helping to focus wave energy along segments of coast coincident to the ridge features (Williams and Meisburger, 1987; Schwab et al., 2000; Hapke et al., 2010b). In fact, Batten (2003) found that a more dissipative shoreface profile along the western reach of the island may help to reduce storm vulnerability by diminishing wave energy as it reaches the shoreline; conversely the steeper offshore slope and subaerial profile configuration may increase storm vulnerability in the eastern reach (Schwab et al., 2000; Batten, 2003; Hapke et al., 2010b). Future modeling efforts that take into account alongshore wave variability may better reflect these offshore dynamics, however, the morphologic changes quantified in this study support current theories as to the relationship between the offshore ridge system and landward migration of Fire Island.

The remains of a relatively younger $\sim 6$-m-thick lobe of Pleistocene glaciofluvial sediment associated with the submerged headland crops out at the seafloor offshore of Watch Hill in water depths of $\sim 12-16 \mathrm{~m}$ (Schwab et al., in press). Figs. 6 and 8 show an overall lack of predicted overwash, limited dune crest movement and elevation change at 26 and $29 \mathrm{~km}$ alongshore, and Fig. 9d shows limited landward profile translation in this location likely related to the occurrence of this younger lobe. Here, the modern Holocene beach wedge can be seen perched on top of the younger outwash lobe (Schwab et al., in press) which we speculate provides a buffer to erosion, island breaching, and landward migration of the more mobile, modern beach wedge. High dunes and abundant beach sediment spatially correspond with the inflection point (change in orientation) of the island (Figs. 5, 6 and 8). Barrier islands have been found to display variable migration patterns where submerged headlands modify wave and current patterns offshore (Riggs et al., 1995), and it is likely that the Pleistocene lobe offshore of Fire Island is having a similar effect. In fact, the area immediately east of the inflection point 
is the portion of the island showing the least erosion of any segment along coast (Figs. 6 and 8 at distances of $\sim 25 \mathrm{~km}$ alongshore).

Farther east, where dunes are generally smaller, sediment supply is limited, and the offshore physiography is different, the island is more vulnerable to storm-induced erosion and overwash. The eastern reach of Fire Island shows a pronounced landward translation of the dunebeach profile (verified through selected profiles), which in some instances show the shoreline of the most recent profile (2009) is nearly landward of the dune crestline of the oldest profile (1969) (Fig. 9e). The eastern reach is where Leatherman (1985) identified a number of former inlets over the last 300 years, and attributed landward migration of the eastern reach primarily to inlet processes transporting sediment to the backbarrier. According to his findings, nearly $85 \%$ of the island has been prone to inlet activity, resulting in island widening at former inlet locations and facilitating landward migration, particularly in the eastern reach. Our results show that average losses of dune crest elevation and landward shifts of the dune crest position are strongly correlated in undeveloped areas predicted to and in many cases observed to overwash during storm events. Limited volume and beach width changes in the eastern reach suggest that the overall profile configuration is conserved over the near-term as it moves landward (Fig. 9e). These results echo those proposed in the conceptual profile translation model by Davidson-Arnott (2005), which theorizes that dune volume is conserved as the sediment eroded from the dune is carried landward, allowing the feature to largely retain its overall shape and appearance. Although the importance of inlets must be acknowledged, these results speak to the importance of overwash on morphology change and island-migration.

In addition to the geologic framework, subaerial sediment availability has likely influenced dune/beach morphology changes in the most recent decade of analysis. Inverse relationships between volume gains in 1969-1999 and losses in 1999-2009, demonstrate that the volume along the length of the island was noticeably higher in the period around 1999 when compared with those of 1969 and 2009. Although the source is unclear, we suspect that the influx of sediment is due to a relatively quiescent weather period, thereby allowing beaches to build gradually over time. The strong correlation between changes in shoreline position, beach width and volume results show that sediment losses occurred along most of the beaches during the latter decade of the study, however, the net progradation of the dune crestline suggests that some of the beach sediment may have been transported to dunes in this period through eolian processes. Short and Hesp (1982) observed that dissipative beaches have the highest eolian sediment transport rates where transgressive dune sheets are often found, and Houser and Mathew (2011) argue that sediment availability rather than transport potential governs dune development on dissipative beaches. For Fire Island, Iribarren numbers calculated for all three datasets based on beach slope show that the volumetrically-increased and widebeach period in 1999 at Fire Island resulted in a distinctly more dissipative profile than the other periods (0.2 in 1999 vs. 0.4-0.5 in 1969 and 2009) with abundant sand for eolian transport and deposition. This may have allowed for an overall transgression of the foredune system alongshore. These results show that in addition to overwash, elevationbuilding appears to be an important process in near-term island migration. Similar to the conceptual model of landward migration in response to the effects of sea level rise proposed by Davidson-Arnott (2005), the displacement of the dunes and beaches in the eastern reach of Fire Island suggests an upward and landward migration of the subaerial and nearshore profile. Our findings show that there is a strong correlation between overwash vulnerability and profile retreat along eastern Fire Island, which support that overwash and eolian transport processes contribute to the landward elevation-building necessary for sustained island migration.

It is also of note that changes observed over 10 and 30-year periods appear to mirror each other, similar to the reversing storm beach hotspots observed by List et al. (2006), although in this case, the earlier period represents one of recovery, whereas the most recent decade reflects post-storm loss. Hapke et al. (2007) documented inverse cells of erosion and accretion that migrated seasonally along coast at Fire Island. However, linear regression rates of shoreline surveys collected over a variety of seasons documented by Lentz and Hapke (2011) in eastern and western study sites between quiescent (1998-2002) and stormy periods (2002-2008) also show similar inverse trends without alongshore migration. Due to the seasonal differences and temporal paucity of our datasets, it is difficult to discern whether observed inverse differences between $\mathrm{T} 1$ and $\mathrm{T} 2$ are due to stormy and less stormy periods or individual events and seasons, though the limited alongshore migration of these features suggests, based on previous work, that behavior in the most recent decade is attributable to a period of relative calm.

Areas of predicted overwash appear to be associated with the severe storms in the early 1990s. Aerial photos from 1994 show extensive overwash and dune erosion along the length of the island, suggesting that the intensity, duration, and temporal density of these storms (a storm every year for three years) is likely to have amplified landward migration of the sediment-starved eastern reach of the island. The longer time scales of our analysis do not allow for assessment of specific storm impacts; however, in contrast to the losses of volume, beach width, and shoreline position, the laterally continuous progradation of the dune crest position along the entire length of coast over T2 suggests a longer term building of the primary dune system, perhaps in the wake of the early 1990s' storms. It is also of note that $69 \%$ of transects persistently predicted to overwash in the near term also overwashed during Hurricane Sandy, suggesting that the vulnerability of the near-term system can be linked with event-driven change, and may be used to anticipate impacts of future storms at specific locations along the coast. If the near-term changes in the eastern reach of Fire Island are largely attributable to the early 1990s' storms as suggested here, the impacts of event-scale occurrences must be considered important drivers of barrier island response and evolution. Should the frequency and intensity of such extreme storms increase in the future, as anticipated in response to climate change, near-term assessments may not only help to spatially anticipate areas of vulnerability, but also to understand where cumulative impacts may serve to accelerate barrier island evolution.

\section{Conclusions}

Multi-decadal morphologic changes to dunes and beaches were quantified at Fire Island using digital elevation models derived from recent lidar surveys and historical aerial photography. Modeled wave run-up was coupled with variations in morphologic features and change to determine the potential impact of storm events the dunes and beach. Our results reinforce the concept that near-term barrier evolution is in part a function of geologic framework and variations in the sediment budget, as demonstrated by differences in behavior of the eastern versus western reaches of Fire Island. We extend this concept to explore variations in the morphology of the cross shore profile and examine the spatial influences of wave climate, human modifications, and the geologic framework on decadal timescales and longer.

Whereas the long-term landward migration of the eastern reach is well established, we found that conservation of volume and a rapid rate of profile translation that suggests overwash is a more dynamic and active process driving landward migration along Fire Island in the near-term than previously suggested. We propose that a propensity for landward migration of the profile on the eastern reach of the island versus the western and central reaches is related to variations in the wave climate due to differences in offshore bathymetry, as well as storm response and recovery. In fact, verification of overwash features in eastern areas persistently predicted to overwash shows that near-term morphologic change assessments can provide important information as to the current and future spatial response of the system to a general storm wave climate. Although we also found that 

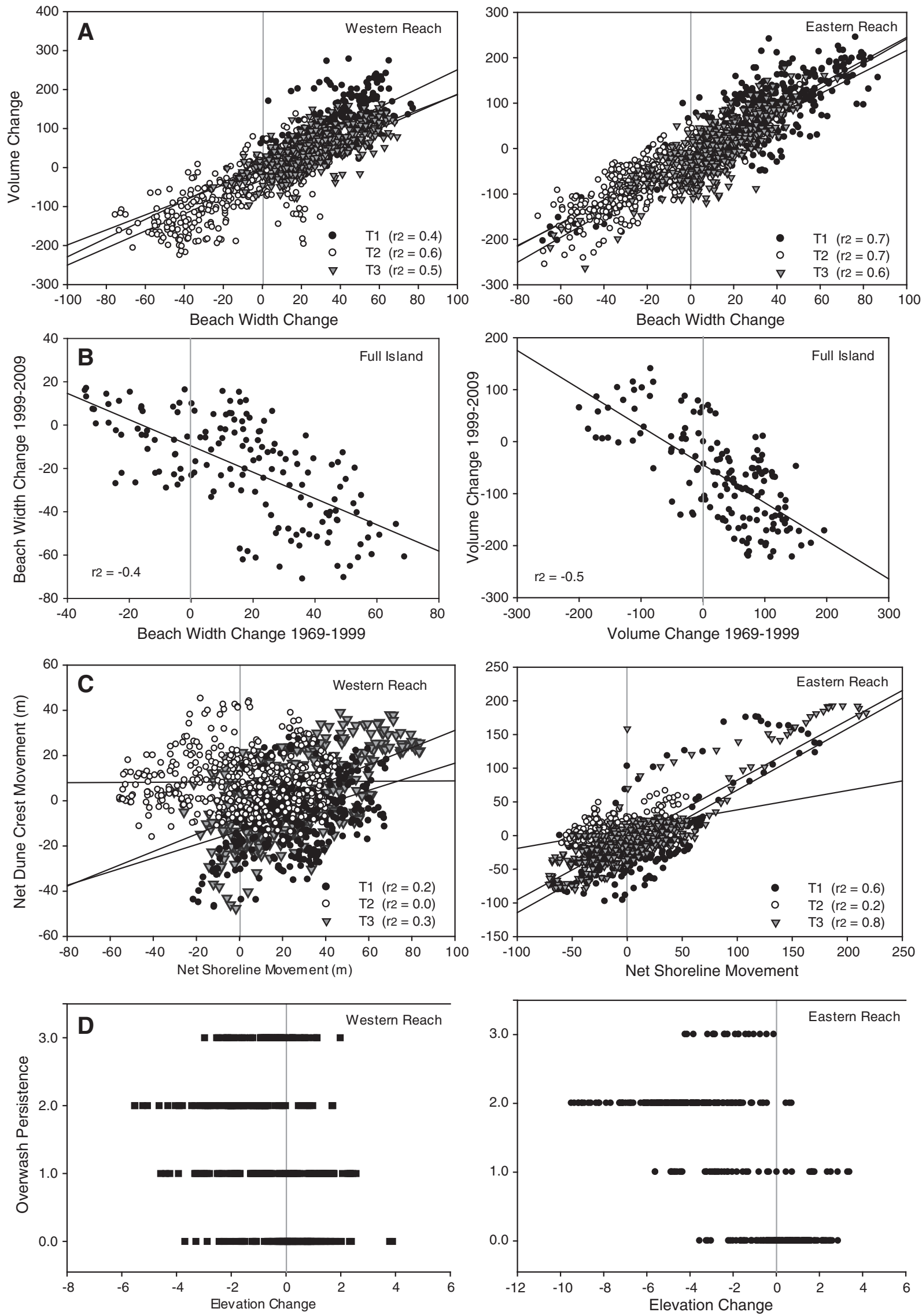

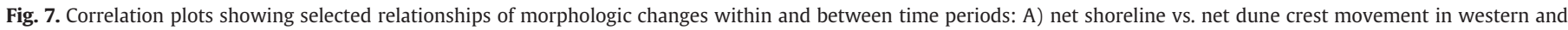

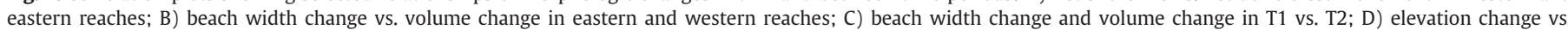
overwash persistence in eastern and western reaches. 


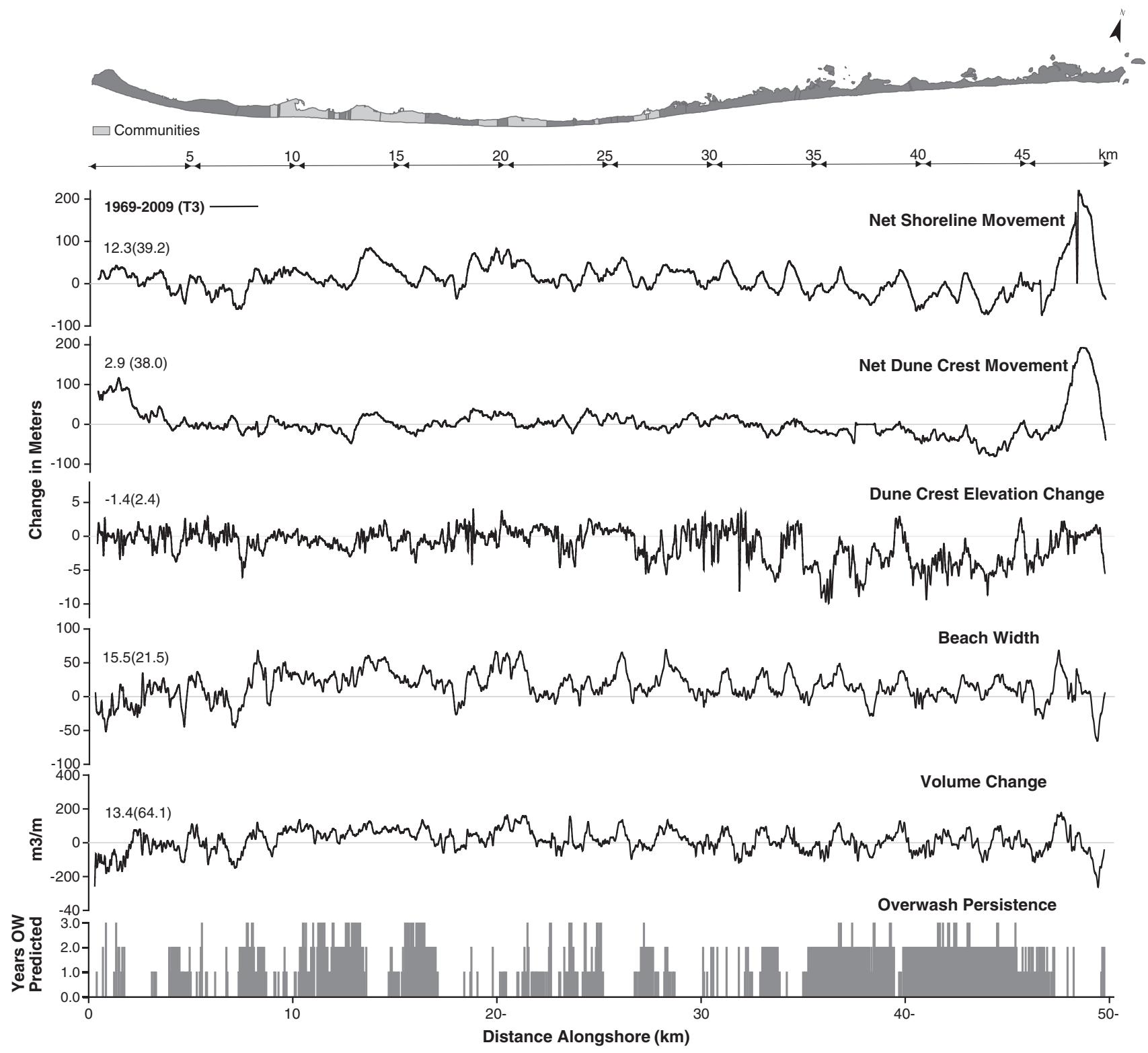

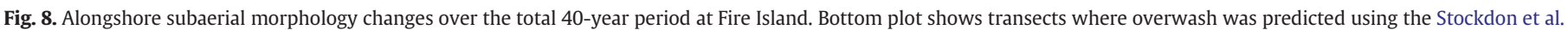
(2007) model and based on the Sallenger (2000) storm impact scale. Mean and standard deviations (parens) for each time period are reported on each plot.

the western portion of the island is predicted to be vulnerable to overwash, we measured less landward translation of the profile, particularly in the areas fronting development, therefore the storm wave climate appears to have less influence on this portion of the island than to the east. This suggests that human modifications in conjunction with the dominant framework controls lead to a more stable profile along western Fire Island. Furthermore, the difficulty in verifying instances of overwash in heavily modified areas is due to development, beach replenishment, and scraping complicating overwash signatures. In addition to change among the two reaches, we observed island-long progradation of the dune crestline over the most recent decade of analysis, despite sediment losses on the beaches affiliated with several large storms of the 2000s. The dune crest progradation is documented in both developed and undeveloped areas in the more recent time period investigated, and is likely due to re-equilibration of the system following the extreme storms of the early 1990s.

This study demonstrates that quantifying an array of near-term patterns of morphology change and linking these with the storm-wave climate, even with temporally sparse datasets, can provide valuable insights into the influence of anthropogenic modifications, storm events, geomorphology, and the geologic framework on coastal change and evolution essential to forecasting behavior and future planning.

Supplementary data to this article can be found online at http:// dx.doi.org/10.1016/j.margeo.2013.02.004.

\section{Acknowledgments}

Funding for this research and graduate student support were provided by the National Park Service, the U.S. Geological Survey, and the University of Rhode Island. Pete August and David Fastovsky read early drafts of this paper and provided helpful comments and suggestions. We are grateful to Bill Schwab for a review of this paper as well as for the fruitful discussions and comments on findings from the USGS geophysical survey off Fire Island in 2011 as well as to Wayne Baldwin and Jane Denny for visual displays of offshore bathymetry. In addition, we appreciate two anonymous reviews which greatly improved the manuscript. 

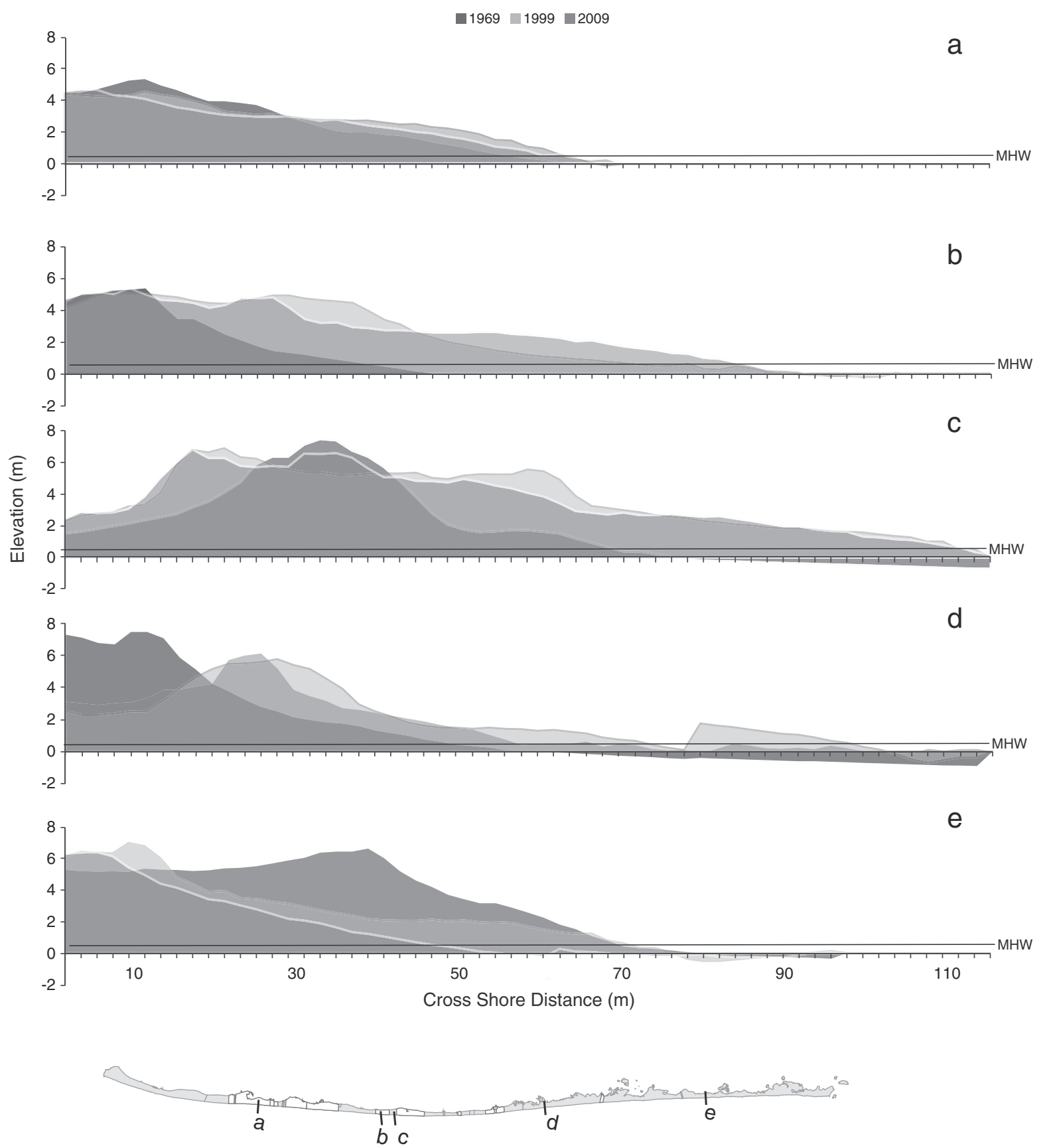

Fig. 9. Selected cross-shore profiles showing subaerial dune-beach changes in the three periods of analysis.

\section{References}

Allen, J.R., LaBash, C.L., August, P.V., Psuty, N.P., 2002. Historical and Recent Shoreline Changes, Impacts of Moriches Inlet, and Relevance to Island Breaching at Fire Island National Seashore: National Park Service Technical Report NPS/BSO-RNR/NRTR/ 2002-7: Boston, MA (76 pp.).

Backstrom, J.T., Jackson, D.W.T., Cooper, J.A.G., 2007. Shoreface dynamics of two high-energy beaches in Northern Ireland. Journal of Coastal Research SI 50, 594-598.

Batten, B.K., 2003. Morphologic Typologies and Sediment Budget for the Ocean Shoreline of Long Island, New York, Marine Sciences Research Center. Stony Brook University, NY, p. 116.

Browder, A.G., McNinch, J.E., 2006. Linking framework geology and nearshore morphology: correlation of paleo-channels with shore-oblique sandbars and gravel outcrops. Marine Geology 231, 141-162.

CP\&E, 2009. 2009 Fire Island Beach Renourishment Project Post-construction Report (37 pp.). Davidson-Arnott, R., 2005. Conceptual model of the effects of sea level rise on sandy coasts. Journal of Coastal Research 21, 1166-1172.

Gravens, M.B., Rosati, J.D., Wise, R.A., 1999. Fire Island Inlet to Montauk Point Reformulation Study (FIMP): Historical and Existing Condition Coastal Processes Assessment: USACE Draft Report, CHL-99-xx (307 pp.).
Hapke, C.J., 2005. Estimation of regional material yield from coastal landslides based on historical digital terrain modelling. Earth Surface Processes and Landforms 30 679-697.

Hapke, C.J., 2009. Integration of Lidar and Historical Maps to Measure Coastal Change on a Variety of Time and Spatial Scales, Chapter 4. In: Wang, Yeqiao (Ed.), Remote Sensing of Coastal Environments, pp. 79-102.

Hapke, C.J., Reid, D., 2007. The National Assessment of Shoreline Change: Part 4: Historical Coastal Cliff Retreat along the California Coast: U.S. Geological Survey.

Hapke, C., Richmond, B., 2000. Monitoring beach morphology changes using small-format aerial photography and digital softcopy photogrammetry. Environmental Geosciences 7, 32-37.

Hapke, C., Richmond, B., 2002. The impact of climatic and seismic events on the short-term evolution of seacliffs based on 3-D mapping: northern Monterey Bay, California Marine Geology 187, 259-278.

Hapke, C.J., Reid, D., Richmond, B.M., Ruggiero, P., List, J.H., 2006. National assessment of shoreline change: Part 3: historical shoreline changes and associated coastal land loss along the sandy shorelines of the California coast. U.S. Geological Survey.

Hapke, C., Lentz, E., Kratzmann, M., Bradley, M., 2007. Multi-Temporal Analysis of Beach Morphology on Fire Island, New York, EOS Trans. AGU 88 (52), Fall Meet. Suppl., Abstract H33L-04. 
Hapke, C.J., Himmelstoss, E.A., Kratzmann, M., List, J.H., Thieler, E.R., 2010a. Nationa Assessment of Shoreline Change; Historical Shoreline Change along the New England and Mid-Atlantic Coasts: U.S. Geological Survey.

Hapke, C.J., Lentz, E.E., Gayes, P.T., McCoy, C.A., Hehre, R.E., Schwab, W.C., Williams, S.J. 2010b. A review of sediment budget imbalances along Fire Island, New York: can nearshore geologic framework and patterns of shoreline change explain the deficit? Journal of Coastal Research 26, 510-522.

Harris, M.S., Gayes, P.T., Kindinger, J.L., Flocks, J.G., Krantz, D.E., Donovan, P., 2005. Quaternary geomorphology and modern coastal development in response to an inherent framework: an example from Charleston, South Carolina. Journal of Coastal Research 21, 49-64.

Hehre, R.E., Hapke, C.J., 2010. Development of Historical Topographic Models of the Beach/Dune system in Northeast Coastal and Barrier Network Parks. NPS Project Report, p. 28.

Houser, C., 2012. Alongshore variation in the morphology of coastal dunes: implications for storm response. Geomorphology 1173-174, 1-16.

Houser, C., Mathew, S., 2011. Alongshore variation in foredune height in response to transport potential and sediment supply: South Padre Island, Texas. Geomorphology $125,62-72$.

Houser, C., Hapke, C., Hamilton, S., 2008. Controls on coastal dune morphology, shoreline erosion, and barrier island response to extreme storms. Geomorphology 100, 223-240.

Judge, E.K., Overton, M.F., 2001. Remote sensing of barrier island morphology: evaluation of phogrammetrically-derived digital terrain models. Journal of Coastal Research 17, 207-220.

Kana, T.W., 1995. A mesoscale sediment budget for Long Island, New York. Marine Geology 126, 87-110.

Kassner, J., Black, J.A., 1983. Fire Island Inet, New York: management of a complex inlet. Shore and Beach 51, 3-8.

Keehn, S., 2004. Challenge and Success at all Levels: The 2003-04 Fire Island Renourishment Projects, Coastal Voice: The Newsletter of the American Shore and Beach Preservation Association. American Shore and Beach, pp. 5-7.

Kratzmann, M.G., Hapke, C., 2012. Quantifying anthropogenically driven morphologic changes on a barrier island: Fire Island National Seashore, New York. Journal of Coastal Research 28, 76-88.

Leatherman, S.P., 1985. Geomorphic and Stratigraphic Analysis of Fire Island, New York. Marine Geology 63, 173-195.

Leatherman, S.P., 1989. Role of inlets in geomorphic evolution of the south shore barriers of Long Island, N.Y., U.S. Environmental Management 12, 109-115.

Leatherman, S.P., Allen, J.R., 1985. Geomorphic Analysis, Fire Island Inlet to Montauk Point, Long Island, New York, Reformulation Study. National Park Service for the U.S. Army Corps of Engineers.

Legendre, P., Fortin, M.J., 1989. Spatial pattern and ecological analysis. Plant Ecology 80, $107-138$

Lentz, E.E., Hapke, C., 2011. Geologic framework influences on the geomorphology of an anthropogenically modified barrier island: assessment of dune/beach changes at Fire Island, New York. Geomorphology 126, 82-96.

List, J.H., Farris, A.S., Sullivan, C., 2006. Reversing storm hotspots on sandy beaches: spatial and temporal characteristics. Marine Geology 226, 261-279.

McNinch, J.E., 2004. Geologic control in the nearshore: shore-oblique sandbars and shoreline erosional hotspots, Mid-Atlantic Bight, USA. Marine Geology 211, 121-141.

Mitasova, H., Overton, M.F., Recalde, J.J., Bernstein, D.J., Freeman, C.W., 2009. Raster-based analysis of coastal terrain dynamics from multitemporal lidar data. Journal of Coastal Research 25, 507-714

Morton, R.A., Miller, T.L., 2005. National assesment of shoreline change: Part 2: historical shoreline changes and associated coastal land loss along the U.S. Southeast Atlantic Coast. U.S. Geological Survey.

Nayeghandi, A, Vivekanandan, S., Brock, J.C., Wright, C.W., Nagle, N.B., Bonisteel-Cormier, J.M., Fredericks, X., Stevens, S., 2011. EAARL coastal topography-Fire Island National Seashore, New York, post Nor'Ida 2009, in: Survey, U.S.G. (Ed.), 1 DVD ed.
NOAA, 2010. National Data Buoy Center. http://www.ndbc.noaa.gov/.

Nordstrom, K.F., McCluskey, J.M., 1985. The effects of houses and sand fences on the eolian sediment budget at Fire Island, New York. Journal of Coastal Research 1, 39-46.

Park, J.-Y., Gayes, P.T., Wells, J.T., 2009. Monitoring beach renourishment along the sediment-starved shoreline of Grand Strand, South Carolina. Journal of Coastal Research 25, 336-349.

Psuty, N.P., Silveira, T.M., 2009. Trend in foredune crestline displacement, Fire Island National Seashore, New York, USA, 1976-2005. Journal of Coastal Research SI 56, 15-19.

Psuty, N.P., Grace, M., Pace, J.P., 2005a. The Coastal Geomorphology of Fire Island: A Portrait of Continuity and Change, Fire Island National Seashore Synthesis. National Park Service, Boston, MA.

Psuty, N.P., Pace, J.P., Allen, J.R., 2005b. Coastal foredune displacement and recovery, Barrett Beach-Talisman, Fire Island, New York, USA. Annals of Geomorphology 141.

Riggs, S.R., Cleary, W.J., Snyder, S.W., 1995. Influence of inherited geologic framework on barrier shoreface morphology and dynamics. Marine Geology 126, 213-234.

Rosati, J.D., Gravens, M., Smith, W., 1999. Regional Sediment Budget for Fire Island to Montauk Point, New York, USA, Coastal Sediments 1999. American Society of Civil Engineers, Hauppauge, New York, pp. 802-817.

Sallenger, A.H., 2000. Storm Impact Scale for Barrier Islands. Journal of Coastal Research $16,890-895$.

Sallenger, A.H., Krabill, W.B., Swift, R.N., Brock, J.C., List, J.H., Hansen, M., Holman, R.A., Manizade, S., Sontag, J., Meredith, A., Morgan, K., Yunkel, J.K., Frederick, E.B., Stockdon, H.F., 2003. Evaluation of airborne topographic lidar for quantifying beach changes. Journal of Coastal Research 19, 125-133.

Schupp, C.A., McNinch, J.E., List, J.H., 2006. Nearshore shore-oblique bars, gravel outcrops, and their correlation to shoreline change. Marine Geology 233, 63-79.

Schwab, W.C., Thieler, E.R., Allen, J.R., Foster, D.S., Swift, B.A., Denny, J.F., 2000. Influence of inner-continental shelf geologic framework on the evolution and behavior of the Barrier-Island System between Fire Island Inlet and Shinnecock Inlet, Long Island, New York. Journal of Coastal Research 16, 408-422.

Schwab, W.C., Baldwin, W.E., Hapke, C.J., Lentz, E.E., Gayes, P.T., Denny, J.F., List, J., Warner, J.C., in press. Geologic Evidence for Onshore Sediment Transport from the InnerContinental Shelf: Fire Island, New York. Journal of Coastal Research.

Short, A.D., Hesp, P.A., 1982. Wave, beach, and dune interactions in southeastern Australia. Marine Geology 48, 259-284.

Stockdon, H.F., Holman, R.A., Howd, P.A., Sallenger, A.H., 2006. Empirical parameterization of setup, swash, and runup. Coastal Engineering 53, 573-588.

Stockdon, H.F., Sallenger, A.H., Holman, R.A., Howd, P.A., 2007. A simple model for the spatially-variable coastal response to hurricanes. Marine Geology 238, 1-20.

Taney, N.E., 1961. Geomorphology of the south shore of Long Island. Beach Erosion Board. U.S. Army Corps of Engineers, p. 67.

Thieler, E.R., Himmelstoss, E.A., Zichichi, J.L., Miller, T.L., 2005. Digital Shoreline Analysis System (DSAS) Version 3.0: An ArcGIS Extension for Calculating Shoreline Change. Open File Report. U.S. Geological Survey.

Thornton, E.B., Sallenger, A., Conforto Sesto, J., Egley, L., McGee, T., Parsons, R., 2006. Sand mining impacts on long-term dune erosion in southern Monterey Bay. Marine Geology 229, 45-58.

Valverde, H.R., Trembanis, C., Pilkey, O.H., 1999. Summary of beach nourishment episodes on the U.S. Journal of Coastal Research 15, 1100-1118.

Weber, K.M., List, J.H., Morgan, K., 2005. An Operational Mean High Water Datum for Determination of Shoreline Position from Topographic LIDAR. U.S. Geological Survey, pp. Open File Report 2005-1027.

Williams, S.J., Meisburger, E.P., 1987. Sand Sources for the Transgressive Barrier Coast of Long Island, New York: Evidence for Landward Transport of Shelf Sediments, Coastal Sediments. American Society of Civil Engineers, New Orleans, LA, pp. 25-40.

Williams, A.T., Morgan, P., 1993. Scanning electron microscope evidence for offshoreonshore sand transport at Fire Island, New York, USA. Sedimentology 40, 63-77. 